\title{
From LTER to LTSER: Conceptualizing the Socioeconomic Dimension of Long-term Socioecological Research
}

\author{
$\underline{\text { Helmut Haberl }}^{1}$, Verena Winiwarter ${ }^{2}$, Krister Andersson $^{3}$, Robert U. Ayres ${ }^{4}$, Christopher Boone ${ }^{5}$,

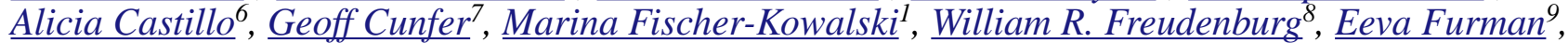 \\ $\underline{\text { Rüdiger Kaufmann }}^{10}$, Fridolin Krausmann $^{11}$, Ernst Langthaler ${ }^{12}$, Hermann Lotze-Campen $^{13}$, \\ Michael Mirtl $^{14}$, Charles L. Redman $^{15}$, Anette Reenberg ${ }^{16}, \underline{\text { Andrew Wardell }}^{16}$ Benjamin Warr $^{17}$, and \\ Harald Zechmeister $^{18}$
}

ABSTRACT. Concerns about global environmental change challenge long term ecological research (LTER) to go beyond traditional disciplinary scientific research to produce knowledge that can guide society toward more sustainable development. Reporting the outcomes of a 2 d interdisciplinary workshop, this article proposes novel concepts to substantially expand LTER by including the human dimension. We feel that such an integration warrants the insertion of a new letter in the acronym, changing it from LTER to LTSER, "Long-Term Socioecological Research," with a focus on coupled socioecological systems. We discuss scientific challenges such as the necessity to link biophysical processes to governance and communication, the need to consider patterns and processes across several spatial and temporal scales, and the difficulties of combining data from in-situ measurements with statistical data, cadastral surveys, and soft knowledge from the humanities. We stress the importance of including prefossil fuel system baseline data as well as maintaining the often delicate balance between monitoring and predictive or explanatory modeling. Moreover, it is challenging to organize a continuous process of cross-fertilization between rich descriptive and causal-analytic local case studies and theory/modeling-oriented generalizations. Conceptual insights are used to derive conclusions for the design of infrastructures needed for long-term socioecological research.

Key Words: communication; governance; land use; long-term ecological research (LTER); long-term socioecological research (LTSER); scale; society-nature interaction; socioecological metabolism; socioecological systems.

\section{INTRODUCTION}

In the past few decades, considerable effort has gone into setting up a network of research and monitoring facilities devoted to long-term ecological research (LTER). LTER projects focus on documenting, analyzing, and explaining ecological patterns and processes operating over long time spans and broad ecological gradients. In particular, one mission of LTER is to detect signals of global environmental change and their impacts on ecosystems across the world (Hobbie et al., 2003, NRC, 2004). Given the large amount of information on several ecosystem compartments required for LTER to be successful, the number and size of LTER facilities is limited. Traditional LTER focuses mainly at the local or "site" level, and on ecosystems under little or no human influence; the two Urban LTER sites are an exception.

The global extent of such natural or semi natural ecosystems, however, is comparably small (Sanderson et al. 2002), and is dwindling rapidly. Moreover, in order to mitigate, and appropriately

\footnotetext{
${ }^{1}$ Institute of Social Ecology, IFF Vienna, Klagenfurt University, ${ }^{2}$ Dept. of Cultural Analysis, IFF Vienna, Klagenfurt University, ${ }^{3}$ University of Colorado, Boulder, Colorado, ${ }^{4}$ INSEAD, Fountainebleau and IIASA, Laxenburg, ${ }^{5}$ School of Human Evolution and Social Change, Global Institute of Sustainability, ${ }^{6}$ Centro de Investigaciones en Ecosistemas, Universidad Nacional Autonoma de Mexic, ${ }^{7}$ Department of History, University of Saskatchewan,

${ }^{8}$ Environmental Studies Programme, University of California, Santa Barbara, ${ }^{9}$ Finnish Environment Institute, SYKE, ${ }^{10}$ Dept. of Zoology and Limnology, University of Innsbruck, ${ }^{11}$ Institute of Social Ecology, IFF Vienna, Austria, ${ }^{12}$ Ludwig Boltzmann Institute of Rural History, St. Pölten, ${ }^{13}$ PIK - Potsdam Institute of Climate Impact Research, ${ }^{14}$ Federal Environment Agency Austria, ${ }^{15}$ International Institute for Sustainability, Arizona State University, ${ }^{16}$ Institute of Geography, University of Copenhagen, ${ }^{17}$ INSEAD, Fountainebleau, ${ }^{18}$ Vienna Ecology Centre, Faculty of Life Sciences, University of Vienna
} 
react to, global environmental change it may be more important to understand the impact of global change on systems in which humans play a major role than to understand its effect on pristine areas (Wilbanks and Kates 1999). This concern challenges LTER to go beyond classical disciplinary research and engage in the production of knowledge useful for solving society's sustainability problems, which require, as most researchers agree, the integrated efforts of both ecologists and social scientists. The LTER network recognized this challenge and convened a series of meetings and workshops, among them a broadly attended one in Tempe, Arizona, in 2000. That meeting resulted in a publication (Redman et al. 2004), which in many ways formed the starting point for the writing of this paper. Other related, parallel initiatives have been underway in the United States such as the human-environment regional observatory (HERO) program (http://hero.geog.psu. edu), and international efforts by the International Geosphere-Biosphere Programme (IGBP), the International Human Dimensions Program (IHDP) such as the Land-Use Land-Cover Change (LUCC) project (http://www.geo.ucl.ac.be/LUCC/lucc.html ), and its successor, the Global Land Project (GLP 2005, http://www.glp.colostate.edu/). A follow-up meeting of social scientists involved in LTER from across the United States in August 2005 reported that much still has to be done (Gragson and Grove 2006). Several scholars who participated in one or both of these activities are authors of this article and carry the accumulated experience of many of these efforts.

Figure 1 shows sustainability as a dynamic balance between socioeconomic demands on ecosystems, and the capacity of ecosystems to maintain resilience while supplying life-supporting services (Haberl et al. 2004). Sustainability thus challenges science to embrace new, interdisciplinary approaches that cut across traditional disciplinary boundaries, thus resulting in the endeavor of "sustainability science" (National Research Council 1999, Kates et al. 2001, Parris and Kates $2003 a, b$, Turner et al. 2003). Sustainability science moves beyond a conventional view that sees human activities as disturbances to otherwise properly functioning ecosystems and recognizes the distinction between local activities and global environmental change (Clark et al. 2004). For LTER to be useful in this context, it has to address socioeconomic concerns and integrate them consistently into both monitoring and analysis, implying a shift from a site-based to a regional approach, i.e., LTSER regions or platforms. A recent paper (Rivera-Monroy et al. 2004) based on 13 case studies demonstrates that such a concept improves the use of LTER for solving pressing environmental and sustainability problems.

To help integrate social science into LTER, the Institute of Social Ecology in Vienna held a workshop jointly sponsored by the IHDP and IGBP programs in February 2005 (http://www.iff.ac.at/so cec/events/workshopltser/). The participants jointly wrote this paper, which summarizes the workshop's outcomes. A unique aspect of the Vienna workshop compared to United States LTER efforts was the substantial input of European researchers who not only bring different intellectual traditions, but also experience working at field stations whose definitions are more diverse than the relatively coherent United States LTER program.

Integrating socioeconomic issues shifts the research focus sufficiently to justify the new label of "longterm socioecological research" or LTSER (Fig. 2). LTSER focuses on socioecological systems, i.e., complex, integrated systems that emerge through the continuous interaction of human societies with ecosystems (Redman et al. 2004). Throughout this paper we use the term "socioecological systems" synonymously with other terms that have been used in the literature such as "coupled humanenvironment systems" (Turner et al. 2003, GLP 2005) and "coupled socio-environmental systems" (GLP 2005, Dearing et al., in press). LTSER not only investigates changes in the state of the environment, but also analyzes societal pressures on ecosystems and the forces driving them, while proposing measures that might alleviate these pressures. Conversely, the effect of ecological change on society, i.e., socioeconomic impact, is a legitimate subject of research. LTSER regards society-nature interaction as a dynamic process in which two autopoietic systems, society, and nature interact (Fischer-Kowalski and Weisz 1999, Weisz et al. 2001). Autopoietic, literally "self-creating," systems are dynamic, self-organized entities that create and reproduce their structure through internal processes, maintain a boundary vis-à-vis their environment, and often evolve over time (Varela et al. 1974).

The key challenge for LTSER is thus to develop concepts for integrated analysis of socioecological systems, which requires interdisciplinary collaboration 
Fig. 1. Sustainability as the dynamic balance between mode of subsistence/lifestyle and the respective historical natural conditions.

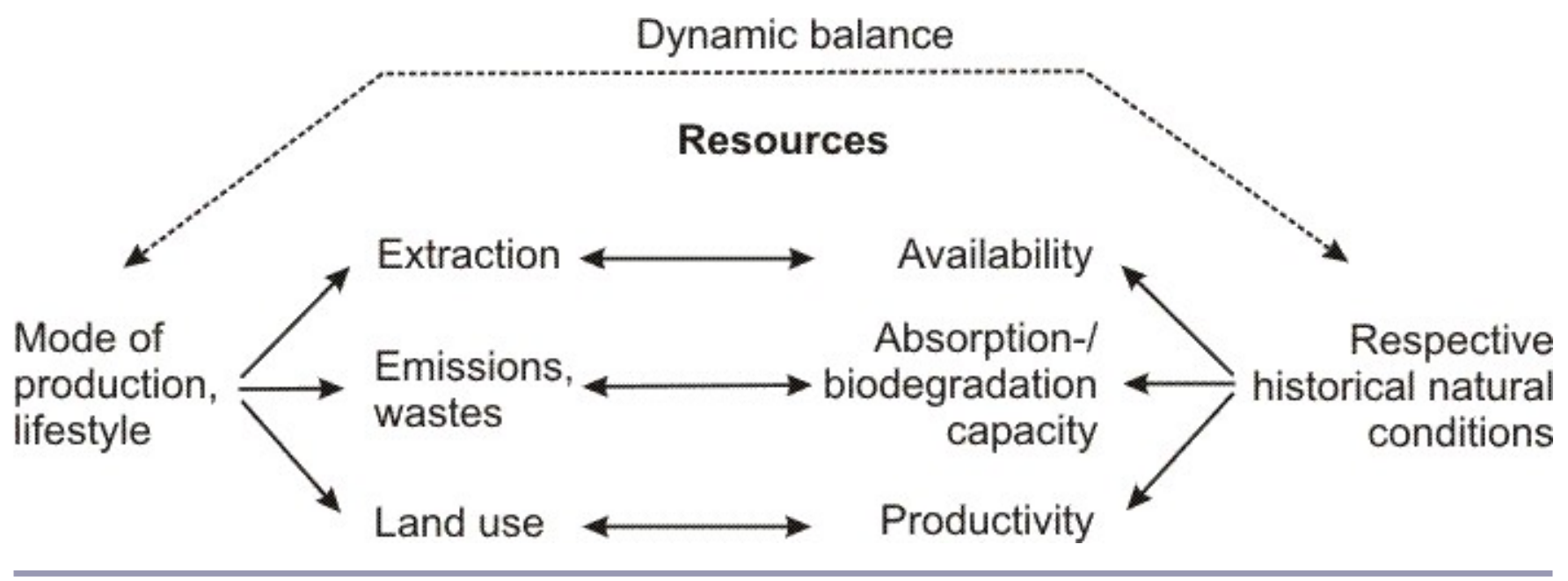

by scholars in the natural and social sciences and the humanities. Such an endeavor faces the following challenges:

- How to conceptualize interaction processes between societies, i.e., human systems integrated by communication, and ecosystems, i.e., biophysical systems integrated by material and energy flows;

- How to deal with issues of scale. Natural boundaries often do not coincide with political and administrative borders, and many societal processes are almost completely independent of geographical space, i.e., trade and modern communication technologies;

- How to distinguish between site-specific and generic dynamics; and

- How to establish links between explanative and predictive modeling, data generated from monitoring, and reconstructions of past situations established by combining historical data from sources and modeling (van der Leeuw 2004).

We believe that a transition to sustainability (Kates and Parris 2003, Parris and Kates, 2003a,b, Clark et al. 2004) if possible, will require fundamental changes in society-nature interaction for which no historical analogues exist (Turner and McCandless 2004). The extent of these changes may be comparable to those associated with the transition from agrarian to industrial society. Historical studies seldom allow one to draw lessons by analogy. But one value of LTSER for sustainability science depends on its ability to capture a centurieslong perspective and to learn from the transition from agrarian to industrial modes of subsistence. Even in regions where the transition from the agrarian to the industrial regime is still underway, or has hardly begun, a centuries-long perspective is often possible thanks to colonial archives (Wardell et al. 2003).

In agricultural societies, limited by technology and high transportation costs, locales or regions, i.e., "hinterlands," had to provide all or most functions necessary for the everyday life of the local population. Under industrial conditions, the spatial division of labor increased. This spatial expansion improved people's ability to meet their needs and 
Fig. 2. Whereas extended LTER focuses on more or less human-modified natural systems, LTSER must deal with socioecological systems that emerge through the interaction between ecosystems and socioeconomic systems.

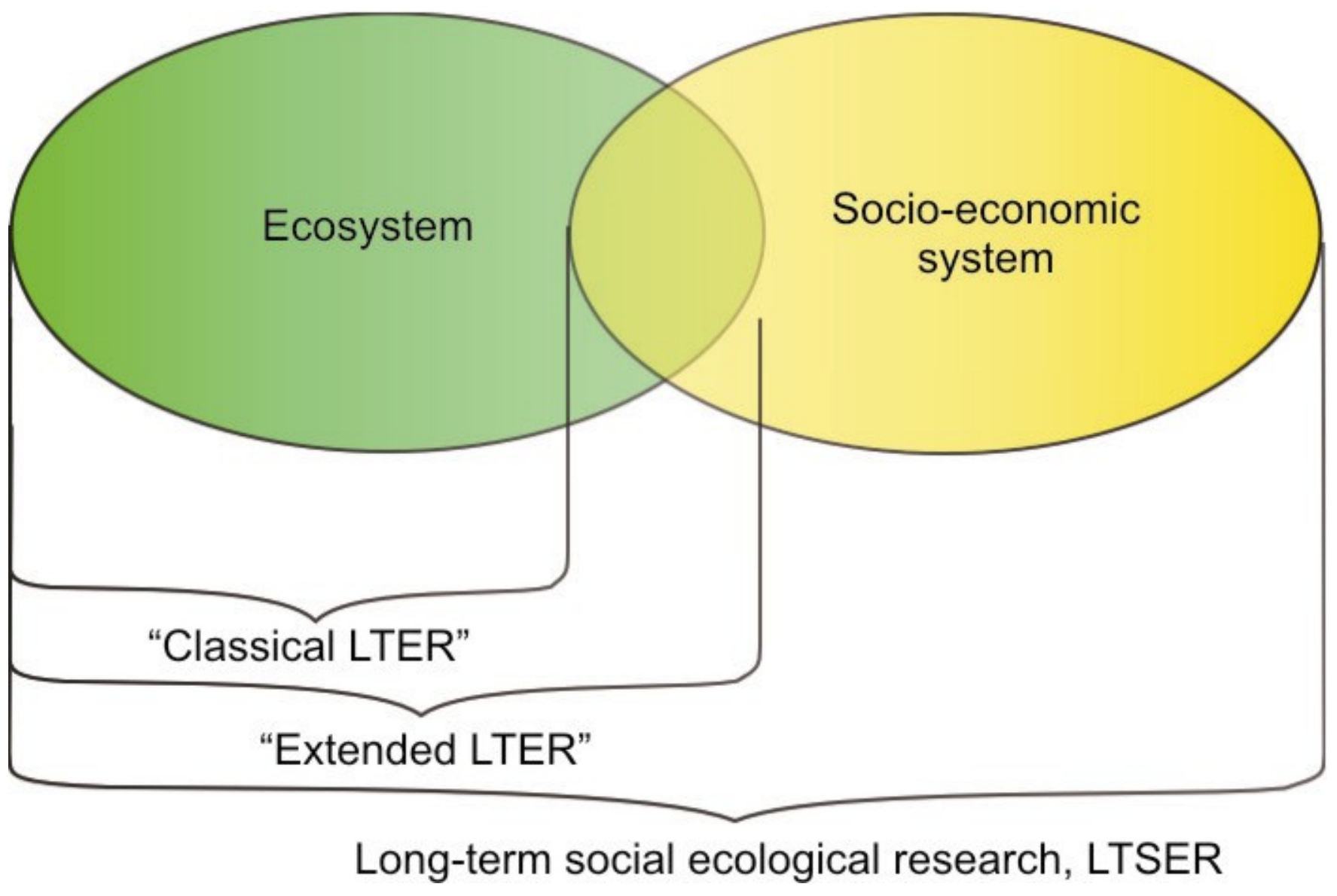

fulfill their social functions because the supply of goods and services was no longer constrained by local resource availability or costly transport. The connections between people's way-of-life and their cultural landscapes weakened (Berglund 1991, Toupal 2003), and it became increasingly difficult to link local and regional ecologies with the behavior and consumption patterns of their human inhabitants.

To address these challenges, we first discuss conceptual requirements of LTSER, then present four core themes of LTSER studies: metabolism, land use, communication, and governance. Finally, we use these themes to discuss future directions of LTSER, identify future research needs, and make recommendations for an appropriate research framework.

\section{CONCEPTUAL REQUIREMENTS OF LONG-TERM SOCIOECOLOGICAL RESEARCH (LTSER)}

\section{[Errata]}

Long-term socioecological research (LSTER) has been one important branch of ecological research during the past decades. For social science to integrate successfully into long-term ecological research (LTER), it is essential to offer a conceptual framework, a heuristic or operational model of 
society-nature interaction that reflects theoretical assumptions, guides methodology, and facilitates substantive interpretations. LTER sites and potential LTSER platforms are, appropriately, highly diverse. To develop a single overarching framework that would be effective everywhere, one has to argue on a generalized level, which might not prove effective. Challenges to sustainability differ depending on local natural resources and social structures. This is poignantly shown by the identification of syndromes of global change (Schellnhuber et al. 1997). Therefore, whereas all LTSER models have to address basic challenges, one of their prerequisites is to set the modeling effort at a suitable, but not too high, level of abstraction. Consequently, we recommend that a series of more specific conceptual or operational models be developed so that each reflects commonalities in a group of LTSER platforms characterized by shared interpretive objectives and socioecological conditions. Hence, the goal for LTSER platforms should be to develop specific LTSER models that are sensitive to the characteristics of their respective sites and research teams.

What we offer here is a set of meta-principles guiding the development of such models. This approach recognizes the widely different objectives and history of LTSER platforms around the world and gives flexibility to researchers, while maintaining coherence to ensure comparability of monitoring and analysis and to provide LTSER with a clear identity. The meta-principles refer to three domains: design, transitions, and research processes and participants.

\section{Design}

LTSER meta-principles encompass the identification of themes for study. Building on previous efforts to develop conceptual frameworks for socioecological interactions (Holling 1986, Ostrom 1990, Boyden 1992, Lee 1993, Ayres and Simonis 1994, FischerKowalski and Haberl 1997, Sieferle 2001, WaltnerToews and Kay 2005), we identify four general themes which are central to any LTSER effort: socioecological metabolism, land use and landscapes, governance, and communication. All four issues require interdisciplinary approaches, as they are crosscutting issues focusing on interactions between social and natural systems. They receive more attention in the next section.
But where are the major driving forces of change, such as population, politics, or the economy, and why are they not the focus here? Organizing our thoughts along these lines could be misleading because the above-mentioned drivers are part of functionally differentiated societal subsystems, and fundamental barriers inhibit communication between such societal subsystems. Functionally differentiated subsystems treat all other subsystems as "environment," but integration between them is difficult, if not impossible (Luhmann 1986). According to Luhmann, each subsystem of society is integrated by a specific communication code; $\mathrm{e}$. g., power in politics or costs in the economy, and these codes are incompatible. Identifying key LTSER themes, which are not tied into one of the functionally differentiated subsystems, is necessary when studying interactions across such subsystems. This is not to deny the importance of any of those systems. Each of our themes calls for exploration of the role of economy, technology, politics, or even religion, but without prioritizing one above the other. Rather than mapping any of these subsystems in the four themes, e.g., talking about land use as an economic or political problem, the themes deserve attention in their own right.

LTSER focuses on interaction processes between social and natural systems. It would be an oversimplification to represent this process solely as either disturbance of nature by humans or as adaptation of humans to natural conditions. Instead, this interaction can be seen as a process of coevolution by two structurally coupled systems (Fischer-Kowalski and Weisz 1999). The conceptual framework needs to account for the fundamental differences between social and natural systems and to find ways to analyze their interaction. As observers we know that what we study is not nature as such. We suggest an approach to the study of natural systems that acknowledges this constraint. We do not wish to deny that cultural representations are useful for our interaction with the outside world.

Natural systems emerge through interdependencies between biophysical processes and may be characterized by describing material and energy flows (Odum 1959). By contrast, the analysis of social systems usually focuses on information flows through countless communication channels characterized by different codes (Luhmann 1986), and is often less concerned with biophysical flows (van der Leeuw and Aschan-Leygonie 2005). 
Fischer-Kowalski and Weisz (1999) suggested studying socioecological systems by viewing society as a hybrid between biophysical and symbolic realms. Fischer-Kowalski and Erb (2003) and Haberl et al. (2004) put this approach into practice by analyzing society's material and energy flows. People incorporate experiences with nature into the symbolic realm of culture not directly, but by means of representation. Within the cultural realm, representations then guide subsequent actions. Although people can minimize the amount of direct physical labor employed in these actions by means of technological artifacts, the interaction remains a biophysical one (Winiwarter 1997). The metabolism of a society, its energy and material throughput, can be measured and accounted for (Fischer-Kowalski 1998, Fischer-Kowalski and Hüttler 1998). The communicative processes that shape this metabolism according to cultural preferences, which might be economically, religiously, or scientifically grounded, depend on the specific culture and can only be understood in cultural terms, e.g., the study of communication itself or of governance, as its political branch.

In both systems, natural and social, research has to cope with processes of markedly different velocities, occurring at the same place and time. It has to account for the cyclical or recurrent properties of some processes, and for feedbacks and nonlinearity (Gunderson and Holling 2002). Society and nature interact on several spatiotemporal scales, a process termed coevolution by those who approach it with a long time perspective in mind (Norgaard 1994, Weisz 2002).

Equally, LTSER research must permit the study of phenomena on different spatial and functional scales (Wilbanks and Kates 1999). Hierarchies of scale have to be accounted for in order to avoid scale mismatches. Similarly, changes in the perception of human relationships to nature, the ecological and social legacies of institutional and jurisprudential models introduced in the past, and of stochastic disturbance events need to be the subject of LTSER studies. Although there is an abundant literature reflecting scale problems (e.g., Allen and Starr 1982, Allen and Hoekstra 1992, Peterson and Parker 1998, Dovers 2000, Gibson et al. 2000), scale has so far received insufficient attention in existing LTER frameworks, as LTER operates mainly at the site level. This will be a major challenge, and LTSER must include multilevel phenomena as well as cross-scale interactions. Coevolutionary approaches encompass a concept of emergent properties, and the scale question might be integrated into such a framework by looking at emergent properties across scales (Norgaard 1994, Weisz 2002).

Existing LTER sites often link poorly, if at all, to socioeconomic monitoring efforts. Both social, e. g., census data, and natural properties, e.g., air, water quality, etc., are monitored, yet these data are largely ignored by LTER research. LTSER should define interfaces to incorporate regional monitoring systems and official statistics and should work with those collecting these data to refine approaches and archive results. Information on socioeconomic systems is patchy and can only be included in LTSER if consistency over time is ensured. Techniques developed by social historians will have to be included in the LTSER toolbox in order to tap these rich sources.

\section{Socioecological transitions}

Socioecological transitions, i.e., fundamental changes in the relation between natural and social systems (Martens and Rotmans 2002, Raskin et al. 2002), are one result of coevolution meriting special attention. In order to understand the challenge of sustainability, such transitions are of particular importance. Transitions from the agrarian to the industrial mode of subsistence entail qualitative changes in the sustainability problems experienced by a society (Haberl et al. 2004). This very transition process is currently underway in developing countries, accompanied by soaring energy consumption and greenhouse gas emissions (Haberl 2006). The industrial revolution expanded human alteration of the global environment to an unprecedented scale and extent (Steffen et al. 2004). Sustainability science must grapple with this transition, in the past and in the present.

Socioecological transitions are not only interesting from the viewpoint of sustainability issues such as energy consumption. They also represent fundamental linkages between social and ecological sciences. The relation a society has to nature is central to its entire makeup, to its social structure and to the type of events it will likely encounter and its coping strategies in response to such events (Godelier 1990, Turner 1992). Changes in societies are closely intertwined with ecological transformations. 
As Godelier has argued, to change society means to change its relationship to nature. Studying such processes over time allows researchers to evaluate the likely consequences of changes suggested by sustainability concepts.

There are at least two approaches toward the role of history in understanding our current socioecological situation. The first could be denoted as the "analogy" approach, characterized by its interest in case studies that have seemingly come to an end. Easter Island, the Mesoamerican Maya, or the Anasazi of Mesa Verde are prominent examples of past collapses (Diamond 2005). From such cases one can only draw rather abstract and general conclusions pertaining to our current situation. It has been argued that we are in a "no-analogy" situation today, with humans having become a geobiophysical force unparalleled in history (Turner and McCandless 2004, Steffen et al. 2004). Therefore it is of limited value to draw conclusions by analogy for sustainable development today.

The second, "legacy," approach argues that history has to be studied because our current situation is dependent on our material and immaterial inheritance. In this framework, "completed" case studies are less interesting than histories of places and people that have a past, present, and future. Examples include communities having to cope with toxic legacies from mining, radioactive contamination, or massive soil erosion. As these legacies show, the coevolutionary trajectory of societies is shaped by their lasting interventions into nature. This creates the need to study the transformations of the geobiophysical arrangements that are at the center of our current practices (Schatzki 2003). Some of these transformations are called transitions because the character of the arrangements in terms of society's metabolism changes drastically. As socioecological systems operate on short and long time scales, we need to study such processes over appropriately long periods.

LTSER will therefore be much more useful for sustainability science if it is able to monitor change over time and recognize the dynamics and impacts of transitions. Shifts from agricultural to industrial economies, from centrally planned to neoliberal politics, from biomass to fossil fuel consumption, from rapid population growth to population stagnation, or historical events such as the colonization of America by Europeans following Christopher Columbus' voyage across the Atlantic, are examples of grand transitions that profoundly modified relationships between social and ecological systems (Sieferle 1997, Turner and Butzer 1992, McNeill 2000). Other transitions may be equally important to consider for a more complete and nuanced understanding of socioecological systems. The ongoing transfer of organisms between Old and New Worlds since 1492 has profoundly altered social and ecological structures around the globe (Crosby 1972, Turner and Butzer 1992). Changing legal frameworks and international treaties, fundamental changes in perceptions and beliefs such as the growth of the modern environmental movement (Dunlap and Mertig, 1991), and overlooked transitions such as female empowerment over resources have transformed socioecological processes and patterns (Mies and Shiva 1993). Institutional and regime change can also disrupt or modify socioecological dynamics (Young 2002).

Baseline data are critical for gauging the temporal dynamics as well as the magnitude and character of transitions. Since social and ecological change can happen over very long periods, it is valuable to mine the past for data in order to detect and discern those transitions. The impacts of successive waves of investment and disinvestment in land use, for example, can be observed only through historical examination. Looking backwards is also critical for examining the impact of historical legacies (Foster et al. 2003) on present-day socioecological systems. Sites can be affected by a multiplicity of legacies: social, ecological, engineered, and institutional. Past ecological conditions, along with social, cultural, and legal structures influence current structures and functions of socioecological systems. The contemporary built environment is a cumulative landscape reflecting varying degrees of addition, erasure, and replacement. The relevance of these factors has to be assessed. A contextualizing approach will include the specificity of a site in terms of perceptions, impacts and responses, and the time lags between the latter two. Examination of legacies also provides a means to examine the unintended consequences of human action, the surprises that were not or could not be foreseen (Holm 2005).

Historical data and present-day monitoring can be used as an empirical basis for scenario building. A longe durée analysis provides a solid empirical basis and an opportunity for scenario or model validation (Leemans and Costanza 2005, Wardell and 
Reenberg 2005). It is well known that activities in the past are key to understanding the current condition of an ecosystem (Foster et al. 2003). Equally important, especially for a socioecological perspective, the past provides insight into the limits to ecosystem and human interactions. Moreover, the legacy of past decisions, especially when they involve land-cover change, landscape transformations, or the built environment guide future options by facilitating certain actions and erecting barriers to others (Gragson and Bolstad 2006). Therefore, analyses based on long-term studies are useful in guiding transitions in ways that lead toward sustainability, a fundamental policy goal of LTSER.

\section{Research process and participants}

The study of society-nature interactions as described above involves researchers trained in different disciplines. It is important that human society addresses the long-term consequences of its interaction with nature. LTSER is more useful to local people and to society at large if it is designed not just as another scientific exercise, but also as a transdisciplinary endeavor. This implies the involvement of local stakeholders (Pezzoli 1997, Brand 2000). Including stakeholders, however, inevitably raises concerns about the roles and selfinterests of researchers in the research process (e. g., Waltner-Toews and Kay 2005). A self-reflective research process explicitly considers the perspectives of involved citizens, scientists, and managers, and the dominant narratives of each of these groups. Cybernetics has termed such a process a second order observation approach. In order to incorporate systematically the contradictory narratives of multiple groups, while enabling self-reflection, LTSER should incorporate processes of perception, valuation, communication, and response into its design. Although we strongly favor a systems approach in the basic research design, that alone will not suffice to include actors, communication, and governance. To tackle these issues LTSER needs to recognize the epistemological distinction between systems and agent-based approaches (Giddens 1984) and to find ways to relate both (Funtowicz and Ravetz 1993). The functional scale problem addressed above means that different types of actors with unique characteristics have to be incorporated within LTSER, e.g., individuals, institutions, organizations, etc.

Such a research process facilitates effective knowledge transfer between the disciplinary domains of scientists, between scientists and policy makers, and between scientists and stakeholders. The problem of communication between different actors cannot be managed easily (Waltner-Toews and Kay 2005). The use of professional "translators" could help to overcome such problems.

\section{THEMES OF LONG-TERM SOCIOECOLOGICAL RESEARCH (LTSER)}

\section{[Errata]}

Any long-term socioecological research (LTSER) project will have to analyze long-term changes in socioecological metabolism, i.e., biophysical flows governed by socioeconomic as well as by natural drivers, i.e., land use and landscapes, and governance, in particular, as it affects the use of natural resources and communication processes, especially those relevant for society-nature interaction. Although in every particular case emphasis can be placed on one or several of these themes, we feel that no LTSER project can completely omit even one, let alone several, of these themes. The following subsections briefly discuss the relevance of each theme, and relate it to the overall LTSER concept.

\section{Socioecological metabolism}

Biologists have defined metabolism as the sum total of the chemical processes that occur in a living organism, resulting in growth, production of energy, i.e., useful work, elimination of waste materials, transport, and reproduction (Beck et al. 1991). The analogy to social systems is obvious: The reproduction of human populations as well as economic production and consumption processes require material and energy flows that have, in their entirety, been denoted as "socioeconomic metabolism" (Ayres and Simonis 1994, FischerKowalski 1998). All of these processes are subject to the laws of thermodynamics and other physical constraints, including land availability, but socioeconomic metabolism is also driven by human activities that are, in turn, directly or indirectly affected by communication processes and governance.

The metabolism concept as applied in recent decades in ecological economics, industrial ecology 
and human ecology has achieved agreed-upon, theoretically grounded definitions of boundaries between societal and natural flows (FischerKowalski and Hüttler 1998, Eurostat 2001). One methodology linked to the metabolism concept is material flow analysis (MFA), which is now incorporated into the collection of official statistics (Eurostat 2002). This approach allows the definition of biophysical structures of society that are driven by human activities, and directly related to ecosystems through material and energy exchanges. In an LTSER context, the metabolism concept can be expanded by explicitly linking socioeconomic flows to the material and energy flows within regional ecosystems. The result is an integrative analysis of a region's full socioecological metabolism, the grand total of socioeconomic and ecological biophysical flows. This in turn facilitates integrated analysis of natural and cultural drivers of change.

The principal measures of socioecological metabolism are physical entities, i.e., stocks and flows of materials and energy that are important characteristics of both ecosystems and industrial and social systems. The flows and stocks of greatest interest in the LTSER context include those of air, water, soil, living biomass, dead organic matter, nutrients, and toxic materials. Global and local biogeochemical cycles involving carbon, oxygen, nitrogen, phosphorous, sulfur, etc. can be, and have been, significantly affected by human activities. Long-term climate change is one of the likely consequences of global socioeconomic metabolism (IPCC 2001). Among the best known consequences are the acidification of the environment resulting from fossil fuel and biomass combustion, and eutrophication from intended as well as unintended release of nitrogen and other plant nutrients, a process that may contribute to biodiversity loss (Bobbink et al. 1998).

Besides agriculture and fisheries, extractive industries such as mining have the greatest impacts on socioecological systems. Urban agglomerations strongly affect socioecological metabolism (Brunner 1994, Lohm et al. 1994). River basins figure prominently in studies of socioecological metabolism, as catchments provide an easy delineation. Major studies of the Hudson River (Ayres and Ayres 1988, Ayres and Tarr 1990) and the Rhine (Stigliani and Anderberg 1993) provide examples. With the increasing capacity of mass transport, social metabolism becomes less and less regional, a fact that also holds true for river basins.

The Hudson-Raritan study discussed in Appendix 1 illustrates the phenomenon of disproportionality (Freudenburg, 2005 Nowak et al. 2006), and shows how industrial activity can leave a legacy of environmental harm for many decades after the activity itself has ceased. This study also shows how indirect methods can provide information at a regional level, for which direct measurements rarely exist. The metabolism approach can help researchers understand coupled systems. Above all, it disentangles the complex interactions of socioeconomic drivers such as economic structure and growth, or lifestyles from ecological drivers such as natural forces, e.g., volcanic eruptions, and human-induced, but external influences such as climate change for scales smaller than global.

An important advantage of the metabolism approach is that it applies on several spatial and functional scales. Although methodological uniformity is most developed at the national level, material flow analysis can work for supranational entities such as the European Union (Eurostat 2002) or for subnational entities such as economic sectors (Schandl et al. 1997), cities, or regions (Brunner 1994, Burke et al. 2002). However, because material- and energy-flow accounts always refer to a defined socioeconomic system, limits to spatial resolution exist. Territories used by socioeconomic systems do not necessarily correspond to "pixels" (Liverman et al. 1998), nor do socioeconomic systems confine their impact to their own territory. This is one important reason why metabolism studies in LTSER should be linked with explicitly spatial studies of society, i.e., nature interactions as described in the next section.

\section{Land use and landscapes}

Cultural landscapes emerge in historical processes through interactions between social systems and ecosystems. As results of coevolutionary processes, they are a biophysical expression of socioecological change through time (Haberl 1999). Cultural landscapes are dynamic; they change as socioeconomic and biophysical systems evolve at a variety of time scales. Dynamics of landscapes are interactive, with socioeconomic drivers affecting natural systems and natural systems driving human activities in a reiterative process (O'Rourke 2005). Cultural landscapes thus reflect the social and 
economic history of a region, including dominant economic activities and their spatial organization, settlement patterns, demography, mobility, and migration. These patterns and processes are, among others, shaped by communication, in particular by the way governance is executed, and simultaneously depend on ecological conditions such as geomorphology and climate and their changes over time (Luig and Oppen 2005).

Land use and its change over time is a critical factor creating landscapes (Gutman et al. 2004, Lambin and Geist 2006). In the absence of humans, landcover patterns reflect natural conditions such as soil, climate, topography, hydrology, and biotic communities. Although dependent on these biophysical conditions, human use of the land results in significant changes to these conditions, often to the extent that human activities largely shape or even control a significant proportion of the biophysical patterns and processes on the landscape level. In cultural landscapes (Berglund 1991, Farina 2000, Buttimer 2001), land cover depends on natural and socioeconomic factors. Whereas biophysical processes, including flows of materials and energy, are relevant for their understanding, studies of cultural landscapes also address perceptions of spatial landscape patterns and their cultural representation (Tuan 1968, Ramakrishnan et al. 1998, Foster et al. 2003). Landscapes are thus socioecological systems, and the analysis of landscape change over decadal and centennial periods is crucially important to render LTSER useful for sustainability science (Leemans and Costanza 2005). For example, Appendix 2 demonstrates how a long time perspective can improve understanding of land-related phenomena, and thus aid in developing better management strategies.

One important parameter to be monitored, reconstructed, and studied, then, is the evolution of land cover over time, including its spatial patterns. Land cover is a readily observable property of landscapes that reflects both natural preconditions and human use. LTSER should strive to understand natural conditions and drivers of their change, socioeconomic conditions, and drivers of their change and the ecological, biophysical, and socioeconomic consequences of land-use and landcover change (GLP 2005). Such studies refer to a range of socioecological systems, including agricultural, forestry, aquatic, and urban landscapes, and their interrelations. Drivers to be considered include demography, institutional forces such as economic structures, government regulation and subsidies, technology, and family dynamics.

In this context the issue of spatial scale is relevant. Trajectories of change are different at the plot, community, landscape, national, and global scales. Case studies suggest that during the past several centuries, forces driving landscape dynamics have often shifted from primarily local to regional, national, or international contexts (Bicik et al. 2001, Krausmann 2001, Krausmann et al. 2003, Wardell et al. 2003). Scale issues are also relevant for analyses of sustainability. For example, nutrient dynamics may appear sustainable at the field level, even when nutrient flows are out of balance at the village level (Krogh 1997). Under current patterns of human mobility, the global communication and trade sustainability of any particular community cannot be judged by analyzing only that particular place. Its spatial reach, or „footprint,“" can extend far beyond its boundaries. Many systems today are maintained by shifting costs elsewhere, in particular to developing countries. Dynamics of such systems cannot be understood from within the system (Fischer-Kowalski and Erb 2003, Wardell 2005). Concepts of sustainability also depend on temporal scale. What appears sustainable over years or decades may not be sustainable over centuries (Fresco and Kroonenberg 1992). Long-term historical studies can help to understand what is possible in terms of sustainability, and what rate of innovation of socioecological systems may be required.

Ecosystem services are of considerable socioeconomic importance (Daily 1997). Land use often maximizes certain services, e.g., biomass production, at the expense of others, e.g., regulation of water flows, biodiversity, resilience (Maass et al. 2005). Moreover, the economic or social value of services strongly depends not only on preferences, but also on the mode of subsistence, e.g., industrial vs. agrarian, market access, and the organization of the economy (Maass et al. 2005).

This means that LTSER transcends traditional LTER in the following respects: It offers a multiscale approach in both space and time. Results from all relevant habitats, including the full range from anthropogenic to pristine systems, have to be integrated into a larger picture. Besides wellestablished core research areas such as inorganic inputs and nutrient cycling, net primary 
productivity, organic matter, biotic communities, etc. already established in LTER studies, LTSER needs to consider a variety of social and economic variables including human demography, political and social institutions and organizations, economic structures, e.g., markets and processes, e.g., production and consumption, as well as perception and communication (Marcussen and Reenberg 1999, Reenberg 2001). How such factors may be integrated into interdisciplinary long-term socioecological studies to gain a more complete understanding than is possible by means of any single disciplinary approach in isolation, is demonstrated in the case study of the "Dust Bowl" included in Appendix 2.

Land-use studies within LTSER can draw from a wealth of methods such as ecological methods for landscape characterization and analysis (Zonneveld and Forman 1990, Naveh and Liebermann 1994), remote-sensing and GIS-based methods for landcover and landscape classification (Liverman et al. 1998, Cunfer 2005), reconstruction of historical land cover based on historical maps and cadastral surveys (Bicik et al. 2001, Krausmann 2001), reconstruction of past, and assessment of present, material and energy flows based on historical and recent statistical data combined with cadastral maps and surveys (Krausmann and Haberl 2002, Cunfer 2004, Krausmann, 2004), or the use of interviews and surveys to characterize households and other important social agents that are molding land use and thus inform mapping of land cover and land use (Reenberg and Fog 1995, Moran and Brondizio 1998). Links to economics exist, such as through the quantification of monetary values of ecosystem services (Costanza et al. 1997, Bockstael et al. 2000, Loreau et al. 2002), although these methods remain controversial. Moreover, approaches from neoclassical economics can contribute considerably to improving our understanding of socioeconomic drivers of land-use change (Geoghegan et al. 1997, Pfaff 1999, Irwin and Bockstael 2002).

\section{Governance and decision making}

In order to support a transition toward sustainability, LTSER goes beyond LTER to explore the decisionmaking processes at different scales to understand conflict as a basis for reconciling divergent goals amongst stakeholders (Adams et al. 2003, Dietz et al. 2003), and to reduce the vulnerability of people, places, and ecosystems (Turner et al. 2003).
Local studies highlight the need for multiple approaches to grasp the complex spatial and temporal dynamics of environmental change (Bassett and Crummey 2003, Lambin et al. 2003, Maass et al. 2005), and the links between social, economic, and environmental change (Tiffin et al. 1994, Beinart and McGregor 2003). A key goal is to understand better the effectiveness of current ecosystem conservation and management. This requires identifying discrepancies between formal rules at different levels of governance, and discovering the gaps between formal and actual practice at each level of governance.

We suggest that one analytical focus be local actors, because they mediate the efforts of other actors at higher levels of governance (Rigg and Nattapoolwat 2001, Andersson 2004, Wardell and Lund 2006). As the analysis of local actors was a cornerstone of the Land-Use Land-Cover Change (LUCC) project (Lambin et al. 1999), and will remain so in the Global Land Project (GLP 2005), such a focus represents another important link between LTSER and land science. Local actors may modify, ignore, or even completely counteract instructions emanating from public policy and regulators. They are nevertheless affected by governance systems at higher scales of influence including national environmental laws, multilateral trade and environmental agreements, and by institutional and jurisprudential antecedents (Barton 2002, Adams and Mulligan 2003). Customary institutions are themselves dynamic and imperfect (Abraham and Platteau 2002). The production and consumption patterns of local actors, on the other hand, reflect economic structures and opportunities as well as technical solutions that are typically developed, established, and reinforced on higher socioeconomic levels. These economic structures, opportunities and technology choices today bear little relation to regional or local ecological conditions, but they guide and constrain decisions by local actors and generate local ecological impacts (FischerKowalski and Erb 2003).

Within LTSER, good governance is understood as the combined effort of society to implement and enforce rules related to the provision of individual and collective goods and services to sustain local livelihoods without compromising ecosystem health. This requires understanding how access to, use, and exchange of resources are managed and negotiated in practice. An urgent overarching question is: How effective are public policies and 
attendant regulatory frameworks at achieving sustainable development? The following issues should be explored within LTSER frameworks to understand what happens in practice at the local level. (See the case studies on property rights in Bolivia and agricultural policy in Austria in Appendix 3.)

- Gaps between formal and actual governance systems: Laws are often subject to routine negotiations, circumvention, or outright nonobservance by a broad array of stakeholders. This does not mean that laws and regulations are not important. In fact, they constitute significant reference points for actors and politico-legal institutions in their negotiations of access and rights, even if they are not enforced.

- Complex networks of actors involved in resource use: Knowledge processes are embedded in social processes. Agency denotes the capacities of local communities to adapt, to harness their own experiences, and to act in accordance with changing circumstances and opportunities. The identification of networks of actors at different scales is critical to the LTSER approach. Local communities are capable of formulating decisions, acting upon them, and innovating or experimenting even under severely restricted conditions (Long and Long 1992).

- The tension between local resource users and external parties: The meaning and effect of law in a particular place depends on the history, the social setting, the power structure, and the dynamic configuration of local and distant opportunities. Local perceptions of resource use can be explored through different lenses such as religious, cultural, sociopolitical, and socioeconomic practices. Environmental history provides a framework to cross-spatial and temporal boundaries (Batterbury and Bebbington 1999, Myllyntaus and Saikku 1999, Pawson and Dovers 2003), and to integrate the multiple influences on, and perceptions of environmental change (Dovers 2000, Hays 2001).
To grapple successfully with the coevolution of social and natural systems on local scales, LTSER requires teams of researchers who are familiar with the respective specific social, economic, political, and ecological contexts (e.g., Reenberg and Fog 1995, Reenberg 2001, Wardell 2005, Wardell and Reenberg 2005). The analysis of long-term socioecological change requires multiple sources of evidence to facilitate data triangulation. These may include the use of historical archives, archaeological and pollen records, oral histories, mapping of land cover and land use dynamics, and the use of existing research networks (Campbell and Sayer 2003, Poteete and Ostrom 2004). Oral traditions can provide useful explanations of relevant social or socio-political relationships. Social memories continue to inform, and to shape the strategies adopted by local resource users in negotiating rights of access to, and use of, land and resources (Hagberg 2003).

LTSER research faces an enormous complexity of actors, processes, interactions, and feedbacks. The difficulties are compounded by spatial and temporal, i.e., scalar, dynamics (Gibson et al. $2000 a$ ), local and national forms of governance that are increasingly challenged by the simultaneous transfer of authority to regional or other multilateral institutions, the incompatibility of goals, particularly in landscapes where several actors hold, and exercise different rights to use the same resource, and a persistently random element in human actions (Berry 1993).

Governance studies within LTSER should address past reductionist perceptions and environmental narratives associated with the role of humans in resource management. They should deconstruct the influence of those perceptions on contemporary policy, management, and conservation schemes. They should develop new, integrated socioecological models and illuminate long-term regional disparities. The International Forestry Resources and Institutions (IFRI) Research Network provides an example of how these complex issues may be addressed by an interdisciplinary research program (Gibson et al. 2000b). There is a need to harness indigenous knowledge, and to listen to interpretations of the local past, while embracing new technologies that help to understand patterns of social and environmental change (Bassett and Crummey 2003, Beinart and McGregor 2003, Hagberg 2003). While pressures on resources grow, 
local conservation and development projects are increasingly giving local resource users control over the resources on which their livelihoods depend. LTSER reminds us who the real custodians of the land are, and that conservation and equity are related objectives (Zerner 2002).

\section{Communication, knowledge, and transdisciplinarity}

Nature as such is inaccessible to us. It is, therefore, also meaningless, unless we assign significance to it. One of the mechanisms by which such significance is created is the distinction between resources and nature. People assign significance through the acquisition of knowledge about nature, a process that depends on communication. The processes of knowledge formation and communication are important to LTSER when dealing with the interface between social uses of nature, in its symbolized, cultural form, and impacts of humans on natural systems. Foucault (1971) discussed the intimate relation between knowledge and power in society. Based on his theory of discourse, Luke (1996) proposed an approach to define the role of environmental sciences in support of governance processes. We suggest incorporating the study of discourse, knowledge formation, and communication into LTSER on two levels.

In a less abstract form, interdisciplinary research teams have long been aware of the issue of communication, in particular when assessing perceptions of change. The change of communicative settings over time is a prime goal of understanding. Perceptions of environmental change vary among different groups (Ribot 1999, Grim 2001, WaltnerToews et al. 2003). Efforts to conflate the past and present are notoriously difficult since they overlook changes in context that defined past environments, and the human conceptions of them. Nevertheless, narratives about social and environmental change are continually promoted and peddled to privilege specific institutions or particular interest groups (Roe 1991). Some dominant ideas still inform policy and shape the actions and strategies used by different resource users despite the lack of empirical evidence to substantiate them.

If one acknowledges the importance of communicative settings and the power structures created through them, the role of the researcher within LTSER must become a theme, too (Waltner-
Toews and Kay 2005). LTSER is interdisciplinary due to its themes: metabolism, landscape, governance, and communication. It is transdisciplinary through its voluntary or involuntary involvement with policy issues. Rather than trying in vain to keep scholarly work detached from policy issues, we suggest a proactive approach that incorporates actor participation and communication. Within LTSER, human groups and individuals are not only objects of study, but actors capable of processing social experience and responding accordingly (Long and Long 1992). Consequently, LTSER has to reflect the fact that its scientific endeavor influences the course of future events.

The social sciences are relevant in gathering data for the construction of adequate pictures of human interactions with ecosystems (Endter-Wada et al. 1998), but they also provide tools for the involvement of scientists and the use of scientific findings in social contexts. A new kind of interaction is therefore expected between LTSER scientists and others that shapes communication processes to facilitate the use of research results (Beal et al. 1986, Röling 1991), and bridges gaps between stakeholders with different perspectives. Through the views and expectations of various actors, in particular those directly affected by socioecological problems, different pictures of a problem emerge that may not coincide with the pictures drawn by scientists (Waltner-Toews et al. 2003). This diverging understanding of problems by different researchers, and by other actors, creates barriers for dialogue and understanding, which are key obstacles to the establishment of partnerships (Walters 1998, Castillo and Toledo 2000).

Research on knowledge generation, communication and use shows that knowledge cannot be packaged, moved, opened, and then used (Beal et al. 1986). The use of knowledge is a complex transactional process, the success of which depends upon a potential user's pre-existing knowledge, beliefs, and experiences. If users are to benefit from science, generators of scientific knowledge must work closely with them to identify problems, find solutions, and involve themselves in decisionmaking processes ranging from the local level to that of policy formulation (Funtowicz et al. 1998, Kates et al. 2001, Castillo et al. 2005). Such transdisciplinary research, that is, research that systematically includes users in the research process, yields innovative questions and methodologies. In addition, including local actors in long-term data 
Table 1. Comparison of key features of LTER and LTSER.

\begin{tabular}{lll}
\hline \hline & LTER & LTSER \\
\hline System studied & Ecosystem & Socioecological system \\
$\begin{array}{l}\text { Humans are dealt with } \\
\text { as... }\end{array}$ & $\begin{array}{l}\text {.human populations, treated like populations } \\
\text { of other species, causing disturbances in } \\
\text { ecosystems. }\end{array}$ & $\begin{array}{l}\text {..human societies/cultures engaged in an } \\
\text { interactive process with their natural } \\
\text { environment. }\end{array}$ \\
Methods/approaches & $\begin{array}{l}\text { Natural sciences approach: observation- } \\
\text { analysis-explanation. Intervention occurs only } \\
\text { in controlled experiments. }\end{array}$ & $\begin{array}{l}\text { Inter- and transdisciplinary approach: gets } \\
\text { involved and is aware that the research may } \\
\text { change the systems under investigation. }\end{array}$ \\
$\begin{array}{l}\text { Products } \\
\text { Expertise, measurement data, models, } \\
\text { understanding of system dynamics. }\end{array}$ & $\begin{array}{l}\text { As LTER plus socioeconomic and statistical } \\
\text { data. Actively uses research results as a basis } \\
\text { for participation in decision making. }\end{array}$ \\
$\begin{array}{l}\text { Basic epistemological } \\
\text { assumptions }\end{array}$ & $\begin{array}{l}\text { Natural-scientific values: aims at objectivity } \\
\text { and reproducibility, may sometimes have the } \\
\text { illusion to be independent of social values and } \\
\text { norms. }\end{array}$ & $\begin{array}{l}\text { Self-reflexivity: is aware that research is a } \\
\text { social process inextricably entangled in } \\
\text { historically contingent social values and norms. }\end{array}$
\end{tabular}

collection such as monitoring (for social monitoring, see Appendix 4), is a cost-effective, empowering way to conduct research. Scientists and users must interact within novel scientific frameworks to define research agendas, set research questions, execute projects, and implement results.

Participatory and action-oriented research can offer LTSER interesting tools for the collective, collaborative, self-reflective, and critical generation of information that helps to solve socioecological problems (Chambers 1995). Participatory approaches, if carried out appropriately, can be liberating, empowering, and educational for stakeholders whose everyday livelihoods depend upon the management of ecosystems, as is the case in many developing countries, and can help bring local communities into the policy debate in a way that validates their knowledge.

The study of communication and the processes of knowledge formation becomes an integral part of LTSER, both as an aim of the study and as a reflective process for the research team. Implementing such an approach involves active participation by LTSER teams in transdisciplinary processes. From traditional radio to modern information technology, interpersonal and group communication serves to share information, to exchange views about problems, and to facilitate negotiations among stakeholders when conflicts arise (Adams et al. 2003). Communication interventions should be designed to enhance dialogue among stakeholders and to promote social learning (Maarleveld and Dangbégnon 1999).

\section{DISCUSSION AND CONCLUSIONS}

\section{Conceptual considerations}

In contrast to long-term ecological research (LTER) which, aside from a small number of urban LTER sites, mostly focuses on studying changes in ecosystems in which current direct human activities are thought to play a minor role, (long-term socioecological research) LTSER focuses on socioecological systems that emerge through the interaction of social and natural systems (Wilbanks and Kates 1999). Combining methods and approaches from various natural-scientific disciplines, LTER is already an interdisciplinary endeavor, but LTSER is far more demanding in this respect, as it also has to bridge the gaps between social and 
natural sciences and the humanities. Table 1 compares some of the key features of LTER and LTSER.

Although these challenges are significant, the four LTSER themes identified here provide a framework that can facilitate such a broadly interdisciplinary research agenda:

- Drawn from ecological economics, industrial ecology and human ecology, the metabolism provides a way to integrate biophysical and socioeconomic processes. With its empirical, quantitative assessments of physical stocks and flows in socioecological systems, analysis of metabolism differentiates between natural and socioeconomic drivers. Analyses of socioecological metabolism combine field data with statistical social data, and use historical sources to reconstruct past states of the system. They thus contribute to socioecological models that integrate economic and ecological dynamics (Ayres 2001, Ibenholt 2002). Stock-flow models may be combined with agent-based models (Janssen 2004) to understand better the interplay between actors' decisions and biophysical flows.

- The land use/landscape approach emphasizes the importance of spatial patterns in socioecological systems. Led by the LandUse Land-Cover Change (LUCC) project (Lambin et al. 1999), recently supplanted by the Global Land Project (GLP 2005), an interdisciplinary scientific community has emerged in the past $15 \mathrm{yr}$ that can contribute valuable conceptual and methodological insights to LTSER. For example, considerable progress has been made in linking social dynamics and spatial patterns, thus addressing critical scaling issues relevant to LTSER (Liverman et al. 1998). Recently, researchers have improved methods to reconstruct long-term changes in landscapes, resulting in a greater consideration of longterm land-use changes (Lambin et al. 2003). Many land science projects have gained from a long-term perspective (e.g., Klepeis and Turner 2001, Foster and Turner 2004, Klepeis 2004) and would benefit from the long-term monitoring efforts integral to a LTSER network. Important linkages exist between metabolism and land use: Changes in socioeconomic metabolism have transformed landscapes (Krausmann et al. 2003). Land use not only provides inputs to socioeconomic metabolism, it also results in changes in ecological material and energy flows (Vitousek et al. 1997).

- The governance approach emphasizes the importance of a broad array of actors and institutions, and of temporal patterns in socioecological systems. In environmental history and political ecology, the governance approach has demonstrated its ability to integrate different periods, to explore the complex multiscalar interactions of different agents of change, and to undertake comparative analyses that highlight the critical importance and contingency of historical contexts. Four issues underpin this approach: understanding the condition and organization of "nature" in the past, exploring the interactions between social conditions, the economy, and the environment, environmental policy and decision making in society in general, and the intellectual history of environmental consciousness (Worster 1977). Among other approaches, environmental history and political ecology have been instrumental in improving our understanding of non-European representations of culture, landscape, and environmental narratives (White 1991, Grove 1995, Fairhead and Leach 1996, Leach and Mearns 1996, Zimmerer and Basset 2003). The actual governance of access to and use of land and natural resources can often put the ambitions of past and future governments into perspective. Laws, regulations, and policies do not determine access to and use of resources as such, but erect a structure of opportunities for negotiation about these rights. The discretionary and capricious enforcement of laws and regulations often provides possibilities for monetary and political rent seeking in the heart of local politics (Wardell and Lund 2006).

- The explicit study of communication and 
knowledge formation in long-term processes of interactions between nature and society allows an assessment of transformations, which includes the role of actors in their networks. As knowledge is a crucial intervening variable in dealing with nature, we need to study its change over time to understand transformation. In addition to the study of governance, which addresses the organization of nature in the past, the study of knowledge and communication allows us to understand mechanisms leading to a particular form of organization, in which noninstitutionalized power structures are included. The study of discourse makes possible a reflection on the role of the research itself in the processes of change. Such a reflexive approach prevents LTSER teams from abusing the knowledge they generate and opens the possibility for active involvement into environmental policy making. By involving stakeholders, those concerned about the issues under consideration, a "transdisciplinary" form of research offers a new way to conceptualize interaction processes as observations involving ourselves and those we study on equal terms.

The issue of research facilities is important. Traditional LTER is organized around relatively small research sites, focusing on single habitats or catchments, often of tens to hundreds of hectares. LTSER requires a different approach, as socioeconomic systems are rarely organized in a spatially explicit way; this fact becomes especially obvious on smaller scales. For example, households are among the smallest relevant social units above the level of the individual, but apart from farm households they often do not have a meaningfully defined "territory." In many socioecological studies, the village or municipality will therefore be the smallest unit of investigation, and higher levels, e.g., districts, provinces, nation states, etc., must not be neglected, as the growth in communication and transportation results in interregional dependency. Moreover, historical and contemporary statistical data, important sources of information within LTSER, only exist for administrative units that often must become the unit of analysis within LTSER. This fact contrasts with the ecological studies that define their units of analysis along natural discontinuities.

Wilbanks and Kates (1999:603) argue that agency, by which they mean intentional human action, is often intrinsically localized, whereas institutions and other regularized, formal social relationships are usually more encompassing and not spatially confined. LTSER therefore needs to transcend the site concept of traditional LTER and adopt a concept of "multifunctional research platforms" (Mirtl 2004), here referred to as LTSER platforms. Such platforms might be on a landscape scale, encompassing larger regions in the range of 10 $1000 \mathrm{~km}^{2}$. LTSER platforms could encompass classic natural-science based LTER sites on which key parameters of important ecosystems or processes are continually monitored and would be complemented by (1) a long-term historical database extracted from archival and statistical sources that reconstructs important socioeconomic changes (Winiwarter 1999, Krausmann 2004, Gutmann et al. 2005) and (2) a socioeconomic monitoring system that traces important contemporary changes and aids decision-making processes (Fischer-Kowalski et al. 2004). Platforms should be seen not only as a physical infrastructure consisting of measurement equipment, etc., but rather as social processes, as attractors for innovative research. LTSER platforms would yield considerable added value by focusing research on a particular region and by integrating multiple cross-fertilizations between several research and monitoring activities and their respective teams. The definition and selection of platforms are therefore of significant importance to cover a broad spectrum of socioecological conditions in a network that spans larger regions.

Integration between LTSER platforms is another important issue. In a globalizing world, isolated landscape-scale studies would fail to address important issues. National and supranational levels must be considered as well, and cooperation between LTSER platforms, e.g., in the form of comparative studies or meta-analyses (Geist and Lambin 2002) are required. Especially important is the inclusion of pre-fossil fuel system baseline data and attention to the often-delicate balance between monitoring and analysis and modeling. It is essential that there be continuous cross-fertilization between rich descriptive and causal-analytic local case studies on the one hand, and theory and modelingoriented generalizations on the other, at multiple scales.

Research networks such as the global, continental, and national LTER networks will play a crucial role 
in this process. Capitalizing on more than two decades of operative experience, important national networks are currently being redesigned. For example, the United States LTER is now adopting the so-called NEON concept (NRC 2004). Funded by the National Science Foundation, a network of universities in the United States has established a "Human-Environment Regional Observatory (HERO) Network" that can provide useful input (http://hero. geog.psu.edu/). Under the auspices of the European Commission, a European LTER network is currently emerging, facilitated by the EU project ALTER-Net (Delbaere 2005; http://www.alter-net. info). Several European countries have decided to establish national networks alongside the international process. All of these conceptual and design initiatives aim to include the human dimension. Such efforts help distinguish sitespecific from general patterns and processes. Broad, general insights are crucial for the whole global change research community.

Integrated socioecological models will play a significant role in LTSER, for several reasons. First, on a landscape scale it is impossible to achieve an integrated picture of ecological processes with measurements alone, so modeling tools, including process-based ecosystem models and GIS models, will be important. Second, historical and statistical data are never sufficient to reconstruct past socioeconomic, let alone socioecological conditions. Various methods, ranging from crosschecks to fullblown integrated models will have to be applied to get a reasonably rich picture (Krausmann 2004, van der Leeuw 2004). Third, models are important tools to integrate social, economic, and ecological parameters in a consistent way, thus aiding interdisciplinary analyses. For example, agentbased modeling approaches have been combined with land-use studies (Parker et al. 2002) and may also be combined with stock-flow models to yield integrated representations of socioecological systems. Fourth, as one important goal of LTSER is to facilitate decision-making processes, models that immediately demonstrate the consequences of different decisions in an interactive process between researchers and stakeholders can be of great help.

LTSER will facilitate the transition to participationoriented, sustainability science (Waltner-Toews and Kay 2005). The scientific community is part of the experiment of modern society, like it or not. The foresight to deal with current problems in a sustainable way cannot be achieved without long- term hindsight, and this is what LTSER can ultimately accomplish.

Responses to this article can be read online at: http://www.ecologyandsociety.org/voll1/iss2/art13/responses/

\section{Acknowledgments:}

We thank our sponsors from the International Human Dimensions of Global Environmental Change (IHDP) and the International GeosphereBiosphere (IGBP) programmes. The workshop was a joint activity of the "Land Use and Cover Change" (LUCC) project hosted by IHDP and IGBP and the "Industrial Transformation" (IT) project hosted by IHDP. We are grateful for additional funding from Klagenfurt University. We thank Gerda Hoschek for her contribution to the organization of the workshop and two anonymous reviewers for comments that helped improve this article.

\section{LITERATURE CITED}

Abraham, A., and J. P. Platteau. 2002. Participatory development in the presence of endogenous community imperfections. The Journal of Development Studies 39(2):104-136.

Adams, W. M., D. Brockington, J. Dyson, and B. Vira. 2003. Managing tragedies: understanding conflict over common pool resources. Science 302:1915-1916.

Adams, W. M., and M. Mulligan. 2003. Decolonizing nature: strategies for conservation in a post-colonial era. Earthscan, London, UK.

Allen, T. F. H., and T. W. Hoekstra. 1992. Toward a unified ecology. Columbia University Press, New York, New York, USA.

Allen, T. F. H., and T. B. Starr. 1982. Hierarchy: perspectives for ecological complexity. University of Chicago Press, Chicago, Illinois, USA.

Andersson, K. 2004. Who talks with whom? The role of repeated interactions in decentralized forest governance. World Development 32(2):233-249. 
Andersson, K., E. Ostrom, and A.Agrawal. 2003. International forestry resources and institutions research network (IFRI). Available online at: $\underline{w w}$ .indiana.edu/ ifri.

Ayres, R. U. 2001. The minimum complexity of endogenous growth models: the role of physical resource flows. Energy 26(9):817-838.

Ayres, R. U., and L. W. Ayres. 1988. An historical reconstruction of major pollutant levels in the Hudson-Raritan basin 1800-1980. National Oceanic and Atmospheric Administration, Rockville, Maryland, USA.

Ayres, R. U., and U. E. Simonis. 1994. Industrial metabolism: restructuring for sustainable development. United Nations University Press, New York, New York, USA.

Ayres, R. U., and J. A. Tarr. 1990. Environmental change in the Hudson River Basin and the HudsonRaritan Estuary. Pages 623-640 in B. L. I. Turner, W. C. Clark, R. W. Cates, J. F. Richards, J. T. Mathews, and W. B. Meyer, editors. The Earth as transformed by human action. Cambridge University Press, Cambridge, UK.

Barton, G.A. 2002. Empire forestry and the origins of environmentalism. Cambridge University Press, Cambridge, UK.

Bassett, T. J., and D. Crummey. 2003. African savannas: global narratives and local knowledge of environmental change. James Currey, Oxford, UK.

Batterbury, S. P. J., and A. J. Bebbington. 1999. Environmental histories, access to resources and landscape change: an introduction. Land Degradation and Development 10(4):279-290.

Beal, G. M., W. Dissanayake, and S. Knonoshima. 1986. Knowledge generation, exchange and utilization. Westview Press, Boulder, Colorado, USA.

Beck, W. S., K. S. Liem, and G. G. Simpson. 1991. Life: an introduction to biology. Harper Collins, New York, New York, USA.

Beinart, W., and J. McGregor. 2003. Social history and African environments. James Currey, Oxford, UK.
Berglund, B. E. 1991. The cultural landscape during 6000 years in southern Sweden: the Ystad Project. Munksgaard International, Copenhagen, Denmark.

Berry, S. 1993. No condition is permanent: the social dynamics of Agrarian change in sub-Saharan Africa. University of Wisconsin Press, Madison, Wisconsin, USA.

Bicik, I., L. Jelecek, and V. Stepanek. 2001. Landuse changes and their social driving-forces in Czechia in the 19th and 20th centuries. Land Use Policy 18(1):65-75.

Bobbink, R., M. Hornung, and J. G. M. Roelofs. 1998. The effects of air-borne nitrogen pollutants on species diversity in natural and semi-natural European vegetation. Journal of Ecology 86:717-738.

Bockstael, N. E., A. M. Freeman, R. J. Kopp, P. R. Portney, and V. K. Smith. 2000. On measuring economic values for nature. Environmental Science and Technology 34:1384-1389.

Boyden, S. V. 1992. Biohistory: the interplay between human society and the biosphere-past and present. UNESCO and Parthenon, Paris, France.

Brand, K.-W. 2000. Nachhaltige entwicklung und transdisziplinarität. besonderheiten, probleme und erfordernisse der nachhaltigskeitsforschung. Analytica, Berlin, Germany.

Brunner, P. H. 1994. Industrial metabolism at the regional and local level. Pages 163-193 in R. U. Ayres and U. E. Simonis, editors. Industrial metabolism: restructuring for sustainable development. United Nations University Press, Paris, France.

Burke, I. C., W. K. Lauenroth, G. A. Cunfer, J. Barrett, A. Mosier, and P. Lowe. 2002. Nitrogen in the central grasslands region of the United States. BioScience 52(9):813-823.

Buttimer, A. 2001. Sustainable landscapes and lifeways: scale and appropriateness. Cork University Press, Cork, Ireland.

Campbell, J. M., and B. A. Sayer. 2003. Integrated natural resource management: linking productivity, the environment and development. Center for International Forestry Research, Jakarta and 
Worldwide Fund for Nature, Gland, Switzerland.

Castillo, A., and V. M. Toledo. 2000. Applying ecology in the Third World: the case of Mexico. BioScience 50(1):66-76.

Castillo, A., A. Torres, A. Velázquez, and G. Bocco. 2005. The use of ecological science by rural producers: a case study in Mexico. Ecological Applications 15(2):745-756.

Chambers, R. 1995. Shortcut and participatory methods for gaining social information for projects. Pages 515-537 in M. M. Cernea, editor. Putting people first: sociological variables in rural development - a World Bank publication. Oxford University Press, Oxford, UK.

Clark, W. C., P. J. Crutzen, and J. J. Schellnhuber. 2004. Science for global sustainability. Pages 1-28 in H. J. Schellnhuber, P. J. Crutzen, W. C. Clark, M. Claussen, and H. Held, editors. Earth system analysis for sustainability. Dahlem Workshop Report 91, MIT Press, Cambridge, Massachusetts, USA.

Costanza, R., R. d'Arge, R. de Groot, S. Fraber, M. Grasso, B. Hannon, K. Limburg, S. Naeem, R. V. O'Neill, and J. Paruelo. 1997. The value of the world's ecosystem services and natural capital. Nature 387:253-260.

Crosby, A. W. 1972. The Columbian exchange: biological and cultural consequences of 1492. Greenwood Press, Westport, Connecticut, USA.

Cunfer, G. 2005. On the Great Plains: agriculture and environment. Texas A\&M University Press, College Station, Texas, USA.

Cunfer, G. A. 2004. Manure matters on the Great Plains frontier. Journal of Interdisciplinary History 34(4):539-567.

Daily, G. C. 1997. Nature's services: societal dependence on natural ecosystems. Island Press, Washington, D.C., USA.

Dearing, J. A., L. J. Graumlich, R. Grove, A. Grübler, H. Haberl, F. Hole, C. Pfister, and S. E. van der Leeuw. In press. Integrating socioenvironment interactions over centennial timescales: needs and issues. In R. Costanza, L. J. Graumlich, and W. Steffen, editors. Integrated history and future of people on Earth. Dahlem Workshop Report 96, MIT Press, Cambridge, Massachusetts, USA.

Delbaere, B. 2005. European policy review: biodiversity research to support European policy. Journal of Nature Conservation 13(2):213-214.

Diamond, J. 2005. Collapse: how societies choose to fail or survive. Allen Lane, London, UK.

Dietz, T., E. Ostrom, and P. C. Stern. 2003. The struggle to govern the commons. Science 302:1907-1912.

Dovers, S. R. 2000. On the contribution of environmental history to current debate and policy. Environment and History 6:131-150.

Dunlap, R. E., and A. G. Mertig. 1991. The evolution of the U.S. environmental movement from 1970 to 1990: an overview. Society and Natural Resources 4(3):209-218.

Endter-Wada, J., D. Blahna, R. Krannich, and M. Brunson. 1998. A framework for understanding social science contributions in ecosystem management. Ecological Applications 8(3):891-904.

Eurostat. 2001. Economy-wide material flow accounts and derived indicators: a methodological guide. Eurostat, European Commission, Office for Official Publications of the European Communities, Luxembourg, Luxembourg.

Eurostat. 2002. Material use in the European Union 1980-2000: indicators and analysis. Eurostat, Office for Official Publications of the European Communities, Luxembourg, Luxembourg.

Fairhead, J., and M. Leach. 1996. Misreading the African landscape: society and ecology in a forestsavanna mosaic. Cambridge University Press, Cambridge, UK.

Farina, A. 2000. The cultural landscape as a model for the integration of ecology and economics. BioScience 50:313-320.

Fischer-Kowalski, M. 1998. Society's metabolism. The intellectual history of material flow analysis. Part I: 1860-1970. Journal of Industrial Ecology 2 (1):61-78. 
Fischer-Kowalski, M., and K.-H. Erb. 2003. Gesellschaftlicher stoffwechsel im raum: auf der Suche nach einem sozialwissenschaftlichen Zugang zur biophysischen Realität. Pages 257-285 in P. Meusburger and T. Schwan, editors. Humanökologie. Ansätze zur Überwindung der Natur-KulturDichotomie. Steiner Verlag, Stuttgart, Germany.

Fischer-Kowalski, M., and H. Haberl. 1997. Tons, joules and money: modes of production and their sustainability problems. Society and Natural Resources 10(1):61-85.

Fischer-Kowalski, M., and W. Hüttler. 1998. Society's metabolism: the intellectual history of material flow analysis. Part II: 1970-1998. Journal of Industrial Ecology 2(4):107-137.

Fischer-Kowalski, M., and H. Weisz. 1999. Society as a hybrid between material and symbolic realms: toward a theoretical framework of societynature interrelation. Advances in Human Ecology 8:215-251.

Fischer-Kowalski, M., K.-H. Erb, and S. J. Singh. 2004. Extending BRIM to BRIA: social monitoring and integrated sustainability assessment. Institute of Social Ecology, Vienna, Switzerland.

Foster, D. R., and B. L. Turner. 2004. The long view: human-environment relationships, $1000 \mathrm{BC}-$ AD 1900. Pages 23-38 in B. L. Turner, J. Geoghegan, and D. R. Foster, editors. Integrated land-change science and tropical deforestation in the Southern Yucatán, final frontiers. Oxford University Press, Oxford, UK.

Foster, D., F. Swanson, J. Aber, I. Burke, N. Brokaw, D. Tilman, and A. Knapp. 2003. The importance of land-use legacies to ecology and conservation. BioScience 53:77-88.

Foucault, M. 1971. L'ordre du discours. Gallimard, Paris, France.

Fresco, L. O., and S. B. Kroonenberg. 1992. Time and spatial scales in ecological sustainability. Land Use Policy 9(3):155-168.

Freudenburg, W. R. 2005. Privileged access, privileged accounts: toward a socially structured theory of resources and discourses. Social Forces 94(1):89-114.
Funtowicz, S. O., and J. R. Ravetz. 1993. Science for the post-normal age. Futures 25(7):739-755.

Funtowicz, S. O., J. Ravetz, and M. O'Connor. 1998. Challenges in the use of science for sustainable development. International Journal of Sustainable Development 1:99-107.

Geist, H. J., and E. F. Lambin. 2002. Proximate causes and underlying driving forces of tropical deforestation. BioScience 52(2):143-150.

Geoghegan, J., L. A. Wainger L.A., and N. E. Bockstael. 1997. Spatial landscape indices in a hedonic framework: an ecological economics analysis using GIS. Ecological Economics 23:251-264.

Gibson, C. C., E. Ostrom, and T. K. Ahn. $2000 a$. The concept of scale and the human dimensions of global change: a survey. Ecological Economics 32 (2):217-239.

Gibson, C. C., M. A. McKean, and E. Ostrom, editors. 2000b. People and forests: communities, institutions and governance. MIT Press, Cambridge, Massechusetts, USA.

Giddens, A. 1984. The constitution of society: outline of the theory of structuration. University of California Press, Berkeley, California, USA.

Global Land Project (GLP). 2005. Science plan and implementation strategy. International GeosphereBiosphere Programme (IGBP) Report Number 53/ IHDP Report Number 19. IGBP Secretariat, Stockholm, Sweden. Available online at: www.glp. colostate.edu/report 53.pdf.

Godelier, M. 1990. Natur, Arbeit, Geschichte. Zu einer universalgeschichtlichen, Theorie der Wirtschaftsformen. Junius, Hamburg, Germany.

Gragson, T. L., and P. V. Bolstad. 2006. Land use legacies and the future of the Southern Appalachia. Society and Natural Resources 19:175-190.

Gragson, T. L., and M. Grove. 2006. Social science in the context of the Long Term Ecological Research program. Society and Natural Resources 19:93-100.

Grim, J. A. 2001. Indigenous traditions and ecology, the interbeing of cosmology and 
community. Harvard University Press, Cambridge, Massachusetts, USA.

Grove, R. H. 1995. Green imperialism: colonial expansion, tropical island edens and the origins of environmentalism, 1600-1860. Cambridge University Press, Cambridge, UK.

Gunderson, L., and C. S. Holling, editors. 2002. Panarchy: understanding transformations in human and natural systems. Island Press, Washington, D. C., USA.

Gutman, G., A. Janetos, C. Justice, E. Moran, J. Mustard, R. Rindfuss, D. Skole, and B. L. Turner, II, editors. 2004. Land change science: observing, monitoring, and understanding trajectories of change on the Earth's surface. Kluwer Academic, New York, New York, USA.

Gutmann, M. P., W. J. Parton, G. Cunfer, and I. Burke. 2005. Population and environment in the U. S. Great Plains. Pages 84-105 in B. Entwisle and P. C. Stern, editors. Population, land use, and environment: research directions. National Research Council, Washington, D.C., USA.

Haberl, H. 1999. Die Kolonisierung der Landschaft. Landnutzung und gesellschaftlicher Stoffwechsel. Pages 491-509 in R. SchneiderSliwa, D. Schaub, and G. Gerold, editors. Angewandte Landschaftsökologie, Grundlagen und Methoden. Springer, New York, New York, USA.

Haberl, H., M. Fischer-Kowalski, F. Krausmann, H. Weisz, and V. Winiwarter. 2004. Progress towards sustainability? What the conceptual framework of material and energy flow accounting (MEFA) can offer. Land Use Policy 21(3):199-213.

Haberl, H. 2006. The global socioeconomic energetic metabolism as a sustainability problem. Energy 31:87-99.

Hagberg, S. 2003. Memories in the making: ritual boundaries and resource use practices in Burkina Faso. Pages 87-106 in D. A. Wardell, A. Reenberg, H. Olsen, and R. Harpoth, editors. Negotiated frontiers in Sudano-Sahelian landscapes: implications for natural resource management strategies. SEREIN Occasional Paper Number 16. Institute of Geography, University of Copenhagen, Copenhagen, Denmark.
Hays, S. P. 2001. Toward integration in environmental history. Pacific Historical Review 70 (1):59-67.

Hobbie, J. E., S. R. Carpenter, N. B. Grimm, J. R. Gosz, and T. R. Seastedt. 2003. The U.S. Long Term Ecological Research Program. BioScience 53:21-32.

Holling, C. S. 1986. The resilience of terrestrial ecosystems: local surprise and global change. Pages 292-320 in W. C. Clark and R. E. Munn, editors. Sustainable development of the biosphere. Cambridge University Press, Cambridge, UK.

Holm, P. 2005. Becoming aware of the sea's potential richness. Newsletter of The International Human Dimensions Program on Global Environmental Change (IHDP) 2/2005:12-13.

Ibenholt, K. 2002. Material flow accounting and economic modeling. Pages 177-184 in R. U. Ayres and L. W. Ayres, editors. A handbook of industrial ecology. Edward Elgar, Northampton, Massachusets, USA.

Intergovernmental Panel on Climate Change (IPCC) 2001. Climate change 2001: synthesis report. Summary for policy makers. IPCC, Geneva, Switzerland.

Irwin, E. G., and N. E. Bockstael. 2002. Interacting agents, spatial externalities and the evolution of residential land use patterns. Journal of Economic Geography 2:31-54.

Janssen, A. M. 2004. Agent-based models. Pages 155-172 in J. Proops and P. Safonov, editors. Modelling in ecological economics. Edward Elgar, Northampton, Massachusetts, USA.

Kates, R. W., W. C. Clark, R. Corell, J. M. Hall, C. C. Jaeger, I. Lowe, J. J. McCarthy, H. J. Schellnhuber, B. Bolin, N. M. Dickson, S. Faucheux, G. C. Gallopin, A. Grübler, B. Huntley, J. Jäger, N. S. Jodha, R. E. Kasperson, A. Mabogunje, P. A. Matson, H. A. Mooney, B. Moore III, T. O'Riordan, and U. Svedin. 2001. Sustainability science. Science 292:641-642.

Kates, R. W., and T. M. Parris. 2003. Long-term trends and a sustainability transition. Proceedings of the National Academy of Science 100:8062-8067. 
Klepeis, P. 2004. Forest extraction to theme parks: the modern history of land change. Pages 39-59 in B. L. Turner, J. Geoghegan, and D. R. Foster, editors. Integrated land-change science and tropical deforestation in the southern Yucatán, final frontiers. Oxford University Press, Oxford, UK.

Klepeis, P., and B. L. Turner. 2001. Integrated land history and global change science: the example of the Southern Yucatán Peninsular Region project. Land Use Policy 18:27-40.

Krausmann, F. 2001. Land use and industrial modernization: an empirical analysis of human influence on the functioning of ecosystems in Austria 1830-1995. Land use policy 18(1):17-26.

Krausmann, F. 2004. Milk, manure and muscular power: livestock and the industrialization of agriculture. Human Ecology 32(6):735-773.

Krausmann, F., and H. Haberl. 2002. The process of industrialization from the perspective of energetic metabolism. Socioeconomic energy flows in Austria 1830-1995. Ecological Economics 41 (2):177-201.

Krausmann, F., H. Haberl, N. B. Schulz, K.-H. Erb, E. Darge, and V. Gaube. 2003. Land-use change and socio-economic metabolism in Austria. Part I: driving forces of land-use change 1950-1995. Land use policy 20(1):1-20.

Krogh, L. 1997. Field and village nutrient balances in millet cultivation in northern Burkina Faso: a village case study. Journal of Arid Environments 35:147-159.

Lambin, E. F., and H. Geist, editors. 2006. Land use and cover change: local processes, global impacts. Springer, New York, New York, USA.

Lambin, E. F., X. Baulies, N. Bockstael, G. Fischer, T. Krug, R. Leemans, E. F. Moran, R. R. Rindfuss, Y. Sato, D. L. Skole, B. L. I. Turner, and C. Vogel. 1999. Land-use and land-cover change (LUCC). Implementation strategy. The International Geosphere-Biosphere Programme (IGBP) and the International Human Dimensions Programme (IHDP), Bonn, Germany.

Lambin, E. F., H. J. Geist, and E. Lepers. 2003. Dynamics of land-use and land-cover change in tropical regions. Annual Review of Environment and
Resources 28(1):205-241.

Leach, M., and R. Mearns. 1996. The lie of the land: challenging received wisdom on the African environment. James Currey and the International African Institute, London, UK.

Lee, K. N. 1993. Compass and gyroscope: integrating science and politics for the environment. Island Press, Washington, D.C., USA.

Leemans, R., and R. Costanza. 2005. Integrated history and future of people on earth (IHOPE). Newsletter of the International Human Dimensions Program (IHDP) 2/2005:4-5.

Liverman, D., E. F. Moran, R. R. Rindfuss, and P. C.Stern. 1998. People and pixels, linking remote sensing and social science. National Academy Press, Washington D.C., USA.

Lohm, U., S. Anderberg, and B. Bergbäck. 1994. Industrial metabolism at the national level: a casestudy on chromium and lead pollution in Sweden, 1880-1980. Pages 103-118 in R. U. Ayres and U. E. Simonis, editors. Industrial metabolism: restructuring for sustainable development. United Nations University Press, New York, New York, USA.

Long, N., and A. Long. 1992. Battlefields of knowledge: the interlocking of theory and practice in social research and development. Routledge, London, UK.

Loreau, M., S. Naeem, and P. Inchausti. 2002. Biodiversity and ecosystem functioning, synthesis and perspectives. Oxford University Press, Oxford, UK.

Luhmann, N. 1986. Ökologische Kommunikation: Kann die moderne Gesellschaft sich aufökologische Gefährdungen einstellen? Westdeutscher Verlag, Opladen, Germany.

Luig, U., and A. Oppen. 2005. The making of African landscapes. Paideuma 43:7-252.

Luke, T. 1996. Generating green governmentality. Available online at: www.cddc.vt.edu/tim/tims/Tim 514a.PDF.

Maarleveld, M., and C. Dangbégnon. 1999. Managing natural resources: a social learning 
perspective. Agriculture and Human Values 16 (267):280.

Maass, J. M., P. Balvanera, A. Castillo, G. Daily, H. Mooney, P. Ehrlich, M. Quesada, A. Miranda, V. Jaramillo, F. Garcia-Oliva, A. MartinezYrizar, H. Cotler, J. Lopez-Blanco, A. PérezJiménez, A. Búrquez, C. Tinoco, G. Ceballos, L. Barraza, R. Ayala, and J. Sarukhán. 2005. Ecosystem services of tropical dry forests: insights from long-term ecological and social research on the Pacific Coast of Mexico. Ecology and Society 10(1): 17 [online] URL: www.ecologyandsociety.org/ vol10/iss 1/art17/.

Marcussen, H. S., and A. Reenberg. 1999. On scale and disciplinarity in the study of natural resource use in the Sahel-lessons from the SEREIN research program. Danish Journal of Geography Special Issue 2:1-14.

Martens, P., and J. Rotmans. 2002. Transitions in a globalising world. Swets and Zeitlinger, Lisse, The Netherlands.

McNeill, J. R. 2000. Something new under the sun: sn environmental history of the twentieth century. Allen Lane, London, UK.

Mies, M., and V. Shiva. 1993. Ecofeminism. Zed Books, London, UK.

Mirtl, M. 2004. LTER in Austria: implementing multifunctional research platforms (MFRPs) for LTER. ILTERN Coordinating Committee Meeting 7-9 July, Manaus, Brazil. Available online at: http: //www.ilternet.edu/meetings/.

Moran, E. F., and E. S. Brondizio. 1998. Land-use change after deforestation in Amazonia. Pages 94120 in D. Liverman, E. F. Moran, R. R. Rindfuss, and P. C. Stern, editors. People and pixels: linking remote sensing and social science. National Academy Press, Washington, D.C., USA.

Myllyntaus, T., and M. Saikku. 1999. Encountering the past in nature: essays in environmental history. Helsinki University Press, Helsinki, Finland.

National Research Council (NRC). 1999. Our common journey: a transition toward sustainability. National Academy Press, Washington, D.C., USA.
National Research Council (NRC). 2004. NEON, addressing the nations environmental challenges. National Research Council (NRC), The National Academy Press, Washington, D.C., USA. Available online at: www.nap.edu.

Naveh, Z., and A. Liebermann. 1994. Landscape ecology, theory and application. Springer, New York, New York, USA.

Nowak, P., S. Bowen, P. E. Cabot. 2006. Disproportionality as a framework for linking social and biophysical systems. Society and Natural Resources 19:153-173.

Norgaard, R. B. 1994. The coevolution of economic and environmental systems and the emergence of unsustainability. Pages 213-225 in R. England, editors. Evolutionary concepts in contemporary economics. University of Michigan Press, Ann Arbor, Michigan, USA.

O'Rourke, E. 2005. Socio-natural interaction and landscape dynamics in the Burren, Ireland. Landscape and Urban Planning 70(1-2):69-83.

Odum, E. P. 1959. Fundamentals of ecology. Saunders, Philadelphia, Pennsylvania, USA.

Ostrom, E. 1990. Governing the commons: the evolution of institutions for collective action. Press Syndicate of the University of Cambridge, Cambridge, Massachusetts, USA.

Parker, D. C., T. Berger, and S. M. Manson. 2002. Agent-based models of land-use and land-cover change. Land-use and Land-cover Change International Project Office (LUCC), Report Series Number 6, Louvain-la-Neuve, Belgium.

Parris, T. M., and R. W. Kates. 2003a. Characterizing a sustainability transition: goals, targets, trends, and driving forces. Proceedings of the National Academy of Science 100:8068-8073.

Parris, T. M., and R. W. Kates. $2003 b$. Characterizing and measuring sustainable development. Annual Review of Environment and Resources 28:559-586.

Pawson, E., and S. Dovers. 2003. Environmental history and the challenges of interdisciplinarity: an antipodean perspective. Environment and History 9:53-75. 
Peterson, D. L., and V. T. Parker. 1998. Ecological scale, theory and applications. Columbia University Press, New York, New York, USA.

Pezzoli, K. 1997. Sustainable development: a transdisciplinary overview of the literature. Journal of Environmental Planning and Management 40 (5):549-574.

Pfaff, A. S. P. 1999. What drives deforestation in the Brazilian Amazon? Journal of Environmental Economics and Management 37:26-43.

Poteete, A., and E. Ostrom. 2004. In pursuit of comparable concepts and data about collective action. Agricultural Systems 82:215-232.

Ramakrishnan, P. S., K. G. Saxena, and U. Chandrasekhara. 1998. Conserving the sacred: for biodiversity management. UNESCO and Oxford and IBH Publishing, New Delhi, India.

Raskin, P., T. Banuri, G. C. Gallopin, P. Gutman, A. Hammond, R. Kates, and R. Swart. 2002. Great transition: the promise and lure of the times ahead. Stockholm Environment Institute, Boston, Massachusetts, USA.

Redman, C. L., J. M. Grove, and L. H. Kuby. 2004. Integrating social science into the long-term ecological research (LTER) network: social dimensions of ecological change and ecological dimensions of social change. Ecosystems 7:161-171.

Reenberg, A. 2001. Agricultural land use pattern dynamics in the Sudan-Sahel-towards an eventdriven framework. Land Use Policy 18:309-319.

Reenberg, A., and B. Fog. 1995. The spatial pattern and dynamics of a Sahelian agro-ecosystem-land use systems analysis combining household survey with georelated information. GeoJournal 37 (4):489-499.

Ribot, J. C. 1999. A history of fear: imagining deforestation in the West African dryland forests. Global Ecology and Biogeography Letters 8:291-300.

Rigg, J., and S. Nattapoolwat. 2001. Embracing the global in Thailand: activism and pragmatism in an era of deagrarianization. World Development 29
(6):945-960.

Rivera-Monroy, V. H., R. R. Twilley, D. Bone, D. L. Childers, C. Coronado-Molina, I. C. Feller, J. Herrera-Silveira, R. Jaffe, E. Mancera, E. Rejmankova, J. E. Salisbury, and E. Weil. 2004. A conceptual framework to develop long-term ecological research and management objectives in the wider Carribean region. BioScience 42:843-856.

Roe, E. 1991. Development narratives, or making the best of blueprint development. World Development 19(4):287-300.

Röling, N. 1991. Extension science: information systems in agricultural development. Cambridge University Press, Cambridge, UK.

Sanderson, E., M. Jaiteh, M. Levy, K. Redford, A. Wannebo, and G. Woolmer. 2002. The human footprint and the last of the wild. BioScience $\mathbf{5 2}$ (10):891-904.

Schandl, H., H. Zangerl-Weisz, J. Lutz, and H. Payer. 1997. Materialbilanz chemie: methodik sektoraler materialbilanzen. Institute of Social Ecology, Social Ecology Working Paper Number 47, Vienna, Austria.

Schatzki, T. R. 2003. Nature and technology in history. History and Theory 42(4):82-93.

Schellnhuber, H., A. Block, M. Cassel-Gintz, J. Kropp, G. Lammel, W. Lass, R. Lienenkamp, C. Loose, M. K. B. Lüdeke, O. Moldenhauer, G. Petschel-Held, M. Plochl, and F. Reusswig. 1997. Syndromes of global change. Gaia 6(1):19-34.

Sieferle, R. P. 1997. Rückblick auf die natur: eine Geschichte des Menschen und seiner Umwelt. Luchterhand, München, Germany.

Sieferle, R. P. 2001. The subterranean forest: energy systems and the industrial revolution. The White Horse Press, Cambridge, Massachusetts, USA.

Steffen, W., A. Sanderson, P. D. Tyson, J. Jäger, P. A. Matson, B. Moore III, F. Oldfield, K. Richardson, H. J. Schellnhuber, B. L. Turner II, and R. J. Wasson. 2004. Global change and the earth system: a planet under pressure. Springer, Berlin, Germany. 
Stigliani, W. M., and S. Anderberg. 1993. Industrial metabolism and long-term risks from accumulated chemicals in the Rhine. Industry and Environment 16(3):30-35.

Tiffin, M., M. Mortimore, and F. Gichuki. 1994. More people, less erosion: environmental recovery in Kenya. Wiley and Sons, Chichester, UK.

Toupal, R. S. 2003. Cultural landscapes as a methodology for understanding natural resource management impacts in the western United States. Conservation Ecology 7(1):12 [online] URL: www .consecol.org/vol7/iss1/art1/.

Tuan, Y. F. 1968. Discrepancies between environmental attitude and behaviour: examples from Europe and China. Canadian Geographer 12:176-191.

Turner, B. L. I., P. A. Matson, J. J. McCarthy, R. W. Corell, L. Christensen, N. Eckley, G. K. Hovelsrud-Broda, J. X. Kasperson, R. E. Kasperson, A. Luers, M. L. Martello, S. Mathiesen, R. Naylor, C. Polsky, A. Pulsipher, A. Schiller, H. Selin, and N. Tyler. 2003. Illustrating the coupled human-environment system for vulnerability analysis: three case studies. Proceedings of the National Academy of Science 100:8080-8085.

Turner, B. L., and K. W. Butzer. 1992. The Columbian encounter and land-use change. Environment 34:16-44.

Turner, B. L., and S. R. McCandless. 2004. How humankind came to rival nature: a brief history of the human-environment condition and the lessons learned. Pages 227-243 in H. J. Schellnhuber, P. J. Crutzen, W. C. Clark, M. Claussen, and H. Held, editors. Earth system analysis for fustainability. Report of the 91st Dahlem Workshop. MIT Press, Cambridge, Massachusetts, USA.

Turner, V. 1992. Prozeß, system, symbol: eine neue anthropologische synthese. Pages 130-146 in R. Habermas and N. Minkmar, editors. Das schwein des häuptlings. Beiträge zur Historischen Anthropologie, Berlin, Germany.

van der Leeuw, S. E. 2004. Why model? Cybernetics and Systems 35(2-3):117-128.

van der Leeuw, S. E., and C. Aschan-Leygonie.
2005. A long-term perspective on resilience in socio-natural systems. Pages 227-264 in H. Liljenström and U. Svedin, editors. Micro, meso, macro: addressing complex systems couplings. World Scientific, Hackensack, New Jersey, USA.

Varela, F. J., H. R. Maturana, and R. Uribe. 1974. Autopoiesis: the organization of living systems, its characterization and a model. Biosystems 5:187-196.

Vitousek, P. M., H.A. Mooney, J. Lubchenco, and J. M. Melillo. 1997. Human domination of Earth's ecosystems. Science 277:494-499.

Walters, C. J. 1998. Improving links between ecosystem scientists and managers. Pages 272-286 in M. L. Pace and P. M. Groffmann, editors. Successes, limitations and frontiers in ecosystem science. Springer, New York, New York, USA.

Waltner-Toews, D., and J. J. Kay. 2005. The evolution of an ecosystem approach: the diamond schematic and an adaptive methodology for ecosystem sustainability and health. Ecology and Society 10(1):38 [online] URL: http://www.ecology andsociety.org/vol10/iss 1/art38/.

Waltner-Toews, D., J. J. Kay, C. Neudoerffer, and T. Gitau. 2003. Perspective changes everything: managing ecosystems from the inside out. Frontiers in Ecology and Environment 1(1):23-30.

Wardell, D. A. 2005. Moving the boundaries of forest and land use history: the case of Upper East Region in northern Ghana. Pages 168-194 in Q. Gausset, M. A. Whyte, and T. B. Thomsen, editors. Beyond territory and scarcity: social, cultural and political aspects of conflicts on natural resource management. Nordic Institute of African Studies, Uppsala, Sweden.

Wardell, D. A., and C. Lund. 2006. Governing access to forests in northern Ghana: micro-politics and the rents of non-enforcement. World Development, in press.

Wardell, A. D., and A. Reenberg. 2005. Farming field expansion strategies in the savanna biome: land use and land cover dynamics in and around the Tiogo forest reserve, Burkina Faso. Pages 19-52 in J. Mistry, and A. Berardi, editors. Savannas and dry forests: linking people with nature. Ashgate, Aldershot, UK. 
Wardell, D. A., A. Reenberg, and C. Toettrup. 2003. Historical footprints in contemporary land use systems: forest cover changes in savannah woodlands in the Sudano-Sahelian zone. Global Environmental Change 13:235-254.

Weisz, H. 2002. Gesellschaft-natur koevolution: bedingungen der möglichkeit nachhaltiger entwicklung. Humboldt Universität, Berlin, Germany.

Weisz, H., M. Fischer-Kowalski, C. M. Grünbühel, H. Haberl, F. Krausmann, and V. Winiwarter. 2001. Global environmental change and historical transitions. Innovation: The European Journal of Social Sciences 14(2):117-142.

White, R. 1991. The middle ground: Indians, empires and republics in the Great Lakes Region, 1650-1815. Cambridge University Press, Cambridge, UK.

Wilbanks, T. J., and R. W. Kates. 1999. Global change in local places: how scale matters. Climatic Change 43:601-628.

Winiwarter, V. 1997. Gesellschaftlicher Arbeitsaufwand für die Kolonisierung von Natur. Pages 161-175 in M. Fischer-Kowalski, H. Haberl, W. Hüttler, H. Payer, H. Schandl, V. Winiwarter, and H. ZangerlWeisz, editors. Gesellschaftlicher Stoffwechsel und Kolonisierung von Natur, ein Versuch in Sozialer Ökologie. Gordon and Breach Fakultas, Amsterdam, The Netherlands.

Winiwarter, V. 1999. Landscape elements in the late medieval village: can information on land-use be derived from normative sources? Medium Aevum Quotidianum 41:22-42.

Worster, D. 1977. Nature's economy: a history of ecological ideas. Cambridge University Press, Cambridge, UK.

Young, O. R. 2002. Are institutions intervening variables or basic causal forces? Causal clusters versus causal chains in international society. Pages 176-191 in M. Brecher and F. Harvey, editors. Millenial reflections on international studies. University of Michigan Press, Ann Arbor, Michigan, USA.

Zerner, C. 2002. Introduction: toward a broader vision of justice and nature conservation. Pages 3-
30 in C. Zerner, editors. People, plants, and justice: the politics of nature conservation. Columbia University Press, New York, New York, USA.

Zimmerer, K. S., and T. J. Bassett. 2003. Political ecology: an integrative approach to geography and environment-development studies. Guilford Press, New York, New York, USA.

Zonneveld, J. I. S., and R. T. T. Forman. 1990 Changing landscapes: an ecological perspective. Springer, New York, New York, USA. 


\section{APPENDIX 1. Socio-ecological Metabolism of the Hudson River Basin.}

River basins provide an opportunity to understand the interactions between human activities and the state of the environment, to observe changes of stocks and flows in the environment over time, and across a range of spatial scales. The Hudson River Basin constitutes an interesting example (see Ayres and Ayres, 1988, Ayres and Tarr, 1990, Tarr and Ayres, 1990). An in-depth study was initiated in 1982 to review the history of fish catches in the Hudson and Raritan Rivers and associated Estuary. The purpose of the study, financed by NOAA, was to establish correlations between fish catches in different stretches of the river and emissions of a specified series of pollutants into the water. Three principle flow paths were considered, direct point source emissions from industrial sites along the river, sewage from urban areas and diffuse non-point pollution in the for, of run-off and leachates from the surrounding land.

One of the interesting features of this case was the radical changes in land use that took place over the period 1880 to 1980 , including dramatic growth in the population of the urban area (New York city and suburbs), and changes in the patterns and intensity of agricultural in the hinterlands. Sewage treatment facilities, including those for storm run-off (storm sewers) were introduced and improved over the period, capable of treating $100 \%$ of by the end of the period. Another major change during the century was the shift from use of coal for household heating to oil and gas, and this resulted in a major change in the quantity and composition of the wastes that were generated and collected during the period. Much of the coal ash was used as landfill under Laguardia Airport. A third major change during the century could be described as de-industrialisation. At the end of the $19^{\text {th }}$ century for example the New York area boasted no less than four large copper refineries, as well as cable manufacturing facilities, other activities associated with the burgeoning market for electrical goods, and chemical products. Polychlorinated biphenols (PCBs) which are highly toxic to fish were being produced as a insulation materials for the electrical industry. Wastes simply accumulated behind a dam on the Mohawk River, a tributary of the Hudson, which circa 1980 gave way, releasing large amounts of PCBs to sediments which are to this day still moving down river. In recent years most of these industries have moved away, New York losing its primacy as an entrepot (oil refineries remained, such as that of Standard Oil). Nowadays the city is centre of finance, retail activity, publishing and consumption. All of these changes have reduced dramatically the immediate emissions burden, however the history of the region still determines the quality of the river ecosystem, its properties and patterns.

The level of copper in the lower Hudson and harbour areas is still exceptionally high due to leaching from wastes from the former copper refineries, the last one of which closed in the mid 1980s. As a result of the aforementioned accident significant levels of PCBs are still measureable. Sediments in New York Bay contain high levels of a suite of heavy metals, thanks to uncontrolled emissions from the chemical industry in the early $20^{\text {th }}$ century. The waters of the bay circulate slowly, sediments accumulate and do not move out to the sea at large. An ambitous project is underway by the Army Corps. Eng. to bury these sediment in a deep hole under the bay itself, hence avoiding issues of reoxidation and mobilisation of toxic metals.

This study illustrates one of the problems and one of the possible approaches to carrying out historical LTSER. The problem is that there is virtually no useable data on pollutants and toxic emissions prior to the 1970s. However, it is possible to make use of historical information on socio-economic activities and conditions to make reasonable estimates of emissions in earlier periods. This was done in the case of the Hudson-Raritan Basin study and a few other cases (Rhine, Danube; see Stigliani and Anderberg, 1993).

\section{References}

Ayres, R. U. and L. W. Ayres. 1988. An historical reconstruction of major pollutant levels in the Hudson-Raritan basin 1800-1980. National Oceanic and Atmospheric Administration, Rockville, MD. Ayres, R. U., and J. A. Tarr. 1990. Environmental Change in the Hudson River Basin and the HudsonRaritan Estuary. Pages B. L. I. Turner, W. C. Clark, R. W. Cates, J. F. Richards, J. T. Mathews, and W. 
B. Meyer, editors. The Earth as Transformed by Human Action. Cambridge University Press, Cambridge.

Stigliani, W. M., and S. Anderberg. 1993. Industrial metabolism and long-term risks from accumulated chemicals in the Rhine. Industry and Environment 16(3):30-35.

Tarr, J. A., and R. U. Ayres. 1990. The Hudson-Raritan Basin. Pages 623-639 in B. L. I. Turner, W. C. Clark, R. W. Kates, J. F. Richards, J. T. Mathews, and W. B. Meyer, editors. The Earth As Transformed by Human Action. Cambridge University Press with Clark University, Cambridge. 


\section{APPENDIX 2. Land Use Case Study: The Dust Bowl.}

As soon as the Dust Bowl began in the early 1930s, observers asked why it happened when and where it did and what caused it. Government bureaucrats quickly provided answers. The Dust Bowl was caused, they said, by the recent arrival of farmers on the southern plains. Settlers had plowed land unsuitable to crop farming, exposing bare soils to high winds. When the 1930s drought arrived dust storms drove miserable people from their homes. Almost immediately the U.S. government set out to reform land use in order to stop the dust storms and to prevent their recurrence (Hurt 1981, Worster 1979).

In the decades since the 1930s scientists have explored the physics of wind erosion. Field and wind tunnel research established the basic parameters of when and how soils erode. William S. Chepil's wind erosion equation (WEQ) identifies five factors that contribute to blowing soils: climatic forces (precipitation, temperature, wind), soil texture, surface roughness, length of field, and quantity of vegetation. By specifying these parameters it is possible to measure and predict wind erodibility. These studies have focused narrowly within the realm of crop agriculture; the WEQ refers specifically to plowed fields. Scientists, assuming that cultivation was the primary cause of dust storms, focused their attention on how farmers should alter land use practices to avoid or diminish the incidence of wind erosion. For example, farmers can plow furrows perpendicular to prevailing winds, rather than parallel to them. They can corrugate their fields by plowing steeper furrows to increase surface roughness. And they can break up long stretches of bare soil with intermittent grass strips (Argabright 1991, Bisal and Hsieh 1966, Lyles and Allison 1976, Woodruff and Siddoway 1965).

This branch of land use and landscape science yielded worthwhile results. But without a broader historical understanding of dust storm dynamics it may be too limited. Historians, for their part, have addressed similar questions. Why did the dust storms happen when and where they did, and what caused them? In the decades after the 1930s historians traced in considerable detail the history of agricultural settlement and land use change on the southern plains between 1870 and 1935. It is clear that in the 30 years before the Dust Bowl farmers plowed a considerable amount of new land for crops (Worster 1979). But there is other historical evidence that does not fit the standard narrative. Carefully drawn maps of the erosion region held in the National Archives indicate that dust storms also happened in places with little cropland, where more than 90 percent of land area remained in native grassland cover (Cunfer 2002, Cunfer 2005). Laborious research in nineteenth century newspapers reveals that repeated, intense dust storms occurred routinely before 1900, when very little of the plains had yet been plowed for crops (Malin 1946). Archeological excavations of Native American occupation of the southern plains show that cultural occupations spanning thousands of years are often separated by deep deposits of wind-blown soils. It appears that dust storms were not a new phenomenon in the 1930s nor were they restricted to high cropping areas. Perhaps dust storms are a routine part of southern plains ecology that arise whenever and wherever there are deep and extended droughts.

The plains have experienced repeated episodes of dust storms over thousands of years. Settlement between 1900 and 1930 put farmers in the path of the next cycle of drought and wind erosion. It is unclear to what extent land use practices may have exacerbated the severity and duration of the Dust Bowl, but the story of causation is more complex than we once thought. The mechanisms of soil erosion in native grassland also remain unexplored. A combination of ecological and socio-economic research can provide a broader and fuller understanding of agroecosystems. Without scientific studies historians may misunderstand the mechanisms of wind erosion. Without historical studies to provide broader temporal and geographic contexts scientists may focus their research too narrowly on cropped fields only. Brought together a LTSER approach can provide broader understanding of human-managed ecosystems that, after all, cover the majority of the earth's land surface.

\section{References}

Argabright, M. S. 1991. Evolution in Use and Development of the Wind Erosion Equation. Journal of Soil and Water Conservation 46:104-105. 
Bisal, F. and J. Hsieh. 1966. Influence of Moisture on Erodibility of Soil by Wind. Soil Science 102:143-146.

Cunfer, G. 2002. Causes of the Dust Bowl. in Past Time, Past Place: GIS for History. ESRI Press, Redlands, CA.

Cunfer, G. 2005. On the Great Plains: Agriculture and Environment. Texas A\&M University Press, College Station.

Gutmann, M. P. and G. Cunfer. 1999. A New Look at the Causes of the Dust Bowl. International Center for Arid and Semiarid Land Studies, Lubbock, TX.

Hurt, R. D. 1981. The Dust Bowl: An Agricultural and Social History. Nelson-Hall, Chicago.

Lyles, B. E. and L. Allison. 1976. Wind Erosion: The Protective Role of Simulated Standing Stubble. Transactions of the American Society of Agricultural Engineers 19:61-64.

Malin, J. 1946. Dust Storms, 1850-1900. Kansas Historical Quarterly 14:129-144,265-297,391-413.

Woodruff, N.P and F.H. Siddoway. 1965. A Wind Erosion Equation. Soil Science Society of America Proceedings 29:602-608.

Worster, D. 1979. Dust Bowl: The Southern Plains in the 1930s. Oxford University Press, New York. 
APPENDIX 3. Governance Case Studies.

\section{Governance case study 1: Introduction of formal property rights in Bolivian forestry}

Prior to 1996, smallholders and indigenous groups in Bolivia were not authorised to harvest any timber resources, not even products for household consumption, without government permits. As a result, formal rules were largely ignored by these groups. Because the central government did not have the financial or the human resources to monitor and enforce the formal rules, they became meaningless in terms of influencing actual forest use. A new regulatory framework introduced in 1996 gave smallholders and indigenous groups formal rights to use all forest resources within their property boundaries. As long as this use is limited to household consumption, no government permits are now needed. For the first time in Bolivian history, previously excluded groups are potentially empowered to harvest timber for commercial purposes, although this requires as many as 27 administrative steps (Andersson and Pacheco, forthcoming, Contreras-Hermosillo and Vargas, 2001). Because of the complicated procedure, very few smallholders have actually been able to take advantage of the opportunities offered by the new set of formal rules. This example shows the limitation of formal rules to influence local people's natural resource use, and illustrates the need for formal rules to consider local practices.

\section{Governance case study 2: Long-term dynamics of governance and land-use change in Austria}

The development of spatial patterns and the intensity of agricultural land use is shaped by environmental constraints, available technology, political regulations and economic conditions, e.g. the development of agricultural markets. In Austria, the years after World War II were characterized by sincere shortage of food and consequent political efforts to increase agricultural production. The so called "green plan" combined the establishment of protected markets and guaranteed prices for agricultural products with financial subsidies for farmers and effectively triggered modernization of the backward structures of Austrian agriculture and an increase in the physical and monetary output of agricultural production. Agricultural modernization was related to a fundamental restructuring of spatial patterns and the intensity of agricultural production: Large-scale mechanization replaced draught animals and labour force, fertilizer and pesticide inputs increased. Specialization and spatial differentiation resulted in a transformation of locally closed agricultural production systems into throughput systems with large external inputs and outputs. This resulted in transfers of large amounts of bulk materials (food, feed and plant nutrients) across large distances both at a national and an international level. Austrian agriculture got increasingly integrated in global markets and consequently the environmental impact of agriculture shifted from a predominantly local level before WWII to a global level. From the 1970s onwards local production and consumption patterns increasingly affected land use in distant regions (Erb, 2004).

In the 1970 s continuing growth in area productivity triggered by guaranteed prices resulted in increasing environmental pressures on agricultural ecosystems and ground water and in severe overproduction. The latter was not competitive on international markets and was significantly subsidised. Political actors reacted slowly but in the mid-1980s Austrian agricultural policy was fundamentally restructured and a range of political measures were implemented to get a grip of the agricultural dilemma. A number of measures, among others, can be highlighted to illustrate this: A newly implemented tax on fertilizer decreased fertilizer application which in turn had a positive impact on ground water contamination. In combination with a fallow program which paid farmers to take cropland out of production this contributed to agricultural extensification. A third measure shifted the subsidy system from guaranteed prices to financial subsidies related to the area under cultivation which slowed down further intensification but still protected small scale farming operations. Finally the government aggressively promoted and subsidised the cultivation of oil and protein crops (so called crop alternatives): This should (1) reduce import dependency with respect to protein feed (large amounts were imported from the US and Brazil), (2) help to reduce overproduction of cereals and (3) substitute biofuels (RME, ethanol) for fossils. These political efforts resulted in significant changes in land use intensity and patterns in the Austrian landscape: Fallow and the new crops increased from $3 \%$ to more than $20 \%$ of cropland between 1985 and 1993 and changed the colour of the Austrian landscape to yellow. Since 
Austria's accession to the European Union the increasing liberalization of agricultural markets triggers the delayed structural adjustment of agriculture. This accelerates reforestation of agricultural areas in regions of marginal productivity and intensification of production in fertile regions. The coming GATT rounds and the expected liberalization are likely to severely affect agriculture in sensitive alpine regions (a reduction in grassland based milk production) and wipe out the production of sugar beets in Austria (Krausmann et al., 2003).

\section{References}

Andersson, K. and D. Pacheco. Forthcoming. Turning to Forestry for a Way Out of Poverty: Is Formalizing Property Rights Enough? In B. Guha-Khasnobis, R. Kanbur, and E. Ostrom, editors. Unlocking Human Potential: Beyond Formality and Informality in Developing Countries. Oxford University Press, Oxford.

Contreras-Hermosilla, A., and T. M. Vargas. 2001. Dimensiones Sociales, Ambientales y Económicas de las Reformas en la Política Forestal de Bolivia. Proyecto de Manejo Forestal Sostenible and the Center for International Forestry Research, Santa Cruz, Bolivia.

Erb, K.-H. 2004. Actual Land Demand of Austria 1926 - 2000: A Variation on Ecological Footprint Assessments. Land Use Policy 21(3):247-259.

Krausmann, F., H. Haberl, N. B. Schulz, K.-H. Erb, E. Darge, and V. Gaube. 2003. Land-use change and socio-economic metabolism in Austria-Part I: driving forces of land-use change: 1950-1995.

Land Use Policy 20(1):1-20. 


\section{APPENDIX 4. Including Users in Baltic Sea Research.}

The Baltic Sea is one of the most-studied seas in the world. It is a semi-enclosed, shallow northern estuary sized $420000 \mathrm{~km}^{2}$ with a drainage area about four times its size. Its natural dynamics are characterized by an interplay of stagnation periods and nutrient-rich upwelling due to salt pulses from the North Sea. This interplay is linked with the frequency and extent of algal blooms because salt pulses break the stagnation period and make nutrients from sediments available to algae in the upper layer of the sea (Furman et al., 2004). Blue green algal blooms are a natural phenomenon of the Baltic Sea and have been recorded as early as 1885 . At present, around 90 million people live in the Baltic Sea's drainage area. Since the mid- $19^{\text {th }}$ century, algal blooms and the overall level of eutrophication has increased in the Baltic Sea due to anthropogenic nutrient discharges. This eutrophication is having various impacts in the ecosystem, including changes in fish populations, increase in filamentous algae, withdrawal of perennial fucoid algae and increased frequency of toxic algal blooms (Kautsky et al. 1986, Lindström and Virtanen 1992, Niemi 1982).

The Archipelago Sea National Park, sized $220 \mathrm{~km}^{2}$ and consisting of thousands of islands, was established in 1983 in the South-West of Finland. It is an area where eutrophication has been clearly demonstrated, and where impacts on humans have arisen (Hänninen and Vuorinen 2001). The Biosphere area of the Archipelago Sea, the core of which is the national park, has 1200 inhabitants. The local inhabitants earn their living, among other things, from fishing, fish farming, agriculture, forestry and tourism. Hundreds of summer cottages owned or rented by people who stay in the area during vacation are situated in the area. In the 1980s, first human and animal toxification reactions caused by blue-green algal blooms were recorded. In addition, conflicts between fish farmers and other residents of the Archipelago Sea deepened due to impacts of smells and the prevalence of slimy algae. The conflict around fish farming has been maintained not least by the provision of contradicting information by various researchers and other stakeholders through the media without a synthesizing analysis (Peuhkuri 2002).

To gain local knowledge and to raise the awareness of users, the Finnish environment institute (SYKE) decided in 1998 to start a process of collecting data of the algal impacts throughout the country. The aim was to provide up-to-date information on the occurrence of cyanobacteria and their spatial and temporal variation during the summer months as a joint-venture of local and regional authorities, SYKE and Finnish Institute of Marine Research (FIMR). This process is still ongoing.

Each week a report is prepared at SYKE which of the following parts: (1) A summary which is a short one-page description of the weekly situation. (2) A map which shows by colour codes the situation at each observation site. (2) A cyanobacterial "abundance barometer" which allows comparison of the current situation to previous years. The barometer is calculated as the balanced mean of the observation sites and cyanobacterial abundance. (4) Descriptions of regional situations are also sometimes included in the report.

The media transmit this up-to-date scientific information, occasionally with big headings, to the users around the Archipelago Sea. The users thus learn about the present extent and impacts of the algal bloom and are thus able to react by calling the algae-line, a telephone line was opened for the users of the coast where anyone can report on the occurence of harmful algae and related problems, and get answers to his or her questions.

When the algae-line was opened in 1998, awareness rose quickly. After the first year, the number of calls reached 200-700 calls /year. No deeper analysis was carried out, however, whether the user reports to the algae-line was based on their reflections of the news or on objective documentation of the algal impacts in their own environment, and thus both alternatives remain as potential options. The aim of the process is to reach a more holistic picture of the algal problem. However, the reflections showed such a high complexity that a synthesizing long term approach such a LTSER would be needed before a 
holistic picture could be drawn and a more balanced communication strategy found.

\section{References}

Furman, E.R., P. Välipakka, H. Salemaa, and R. Munsterhjelm. 2004. Baltic Sea, Environment and Ecology. University of Helsinki, Maj and Tor Nessling Foundation, Ministry of Environment, Finnish Environment Institute and Southeast Regional Environment Centre. [online] URL http://www. environment.fi/balticsea.

Hänninen J., and I. Vuorinen. 2001. Macrozoobenthos structure in relation to environmental changes in the Archipelago Sea, northern Baltic Sea. Boreal Environment Research 6:93-105.

Kautsky, N., H. Kautsky, U. Kautsky, and M. Waern. 1986. Decreased depth penetration of Fucus vesiculosus (L.) since the 1940's indicates eutrophication of the Baltic Sea. Marine Ecology Progress Series 28:1-8.

Lindström T., and T. Virtanen. 1992. A bloom of Prymnesium parvum Carter in a small coastal inlet in Dragsfjärd, Southwestern Finland. Environmental Toxicology and Water Quality 7:165-170.

Niemi, A. 1982. Plankton blooms in the central and nothern Baltic Sea. International Council for the Exploration of the Sea, Report ICES CM 1982/2(10), Copenhagen, Denmark.

Peuhkuri, T. 2002. Knowledge and Interpretation in Environmental Conflict. Fish-farming and Europhication in the Archipelago Sea, SW Finland. Landscape and Urban Planning 61:157-168. 